\title{
Review of Humanitarian Refuge in the United Kingdom: Sanctuary, Asylum, and the Refugee Crisis
}

\author{
YASMIN IBRAHIM (D) \\ University of London \\ ANITA HOWARTH (D) \\ Brunel University
}

This article traces the U.K.'s tepid response to the recent refugee crisis confronting Europe today and reviews Britain's approach to provide sanctuary from its ideologicallhistorical origins to its policy enactments over time (1905-2016). That approach resonates with the deep tensions the issue of immigration raises within the nation state and the intense uncoupling of refuge and sanctuary from its humanitarian initiatives. We juxtapose the U.K. government's engagement with the refugee crisis against its "tradition of humanitarianism" in which Britain has idealized itself as sanctuary to those who have fled from persecution, torture, or conflict. This historic ideal of refuge has been challenged with numerous immigration and asylum-related policies as well as increased securitization of border controls in response to the changing political context since 1905. We argue that "sanctuary" is a diminished and contentious component of its present-day humanitarianism involving increased securitization and asylum policies with stringent immigration controls. We trace the U.K.'s harsh and restrictive stance toward the refugee and the asylum seeker through a series of policies from the Aliens Act in 1905 to the Dubs Amendment of 2016 which seek to delegitimize refugees, enact tighter barriers to entry, and cast them as economic "migrants" and as suspect figures in a post-9/11 world.

Keywords: Immigration Policy, Refugees, Refugee Crisis, Migration, Asylum Seekers, Sanctuary, United Kingdom, Great Britain, British Immigration History, 1905-2016, Brexit, Border Control, Humanitarianism,

\footnotetext{
Acknowledgements: We are grateful for the careful reading and constructive comments of the $P \& P$ reviewers in strengthening this article from its earlier version. We are also indebted to the Editor, Prof. David Mena Alemán, for his invaluable counsel and clear directions in refining this article.
} 
Europe, European Union, Border Controls, Theresa May, Racialized Discourse, Othering, Aliens 1905, Humanitarian Crisis, Calais, Calais Jungle, Refuge.

\section{Related Articles:}

Duman, Yoav H. 2014. "Reducing the Fog? Immigrant Regularization and the State." Politics \& Policy 42 (2): 187-220. http://onlinelibrary. wiley.com/doi/10.1111/polp.12065/abstract

McKay, Fiona H., Lucy Hall, and Kehla Lippi. 2017. "Compassionate Deterrence: A Howard Government Legacy." Politics \& Policy 45 (2): 169-193. http://onlinelibrary.wiley.com/doi/10.1111/polp.12198/abstract Silverman, Stephanie J. 2012. “'Regrettable but Necessary?' A Historical and Theoretical Study of the Rise of the U.K. Immigration Detention Estate and Its Opposition." Politics \& Policy 40 (6): 1131-1157. http:// onlinelibrary.wiley.com/doi/10.1111/j.1747-1346.2012.00393.x/abstract

\section{Related Media:}

Gentleman, Amelia. 2015. "'What Crime Have I Committed to be Held Like This?': Yarl's Wood." The Guardian. March 3. https://www.theguardian.com/uk-news/2015/mar/03/inside-yarls-wood-detention-centre-asylumseekers-abuse-suicide

Polachowska, Maria. 2012. "Kindertransport: A Journey to Life." BBC Newsnight. https://www.youtube.com/watch?v=XqP0uVSj3bQ UNHCR. 2017. "Global Trends: Forced Displacement in 2016.” http:// www.unhcr.org/uk/statistics/unhcrstats/5943e8a34/global-trends-forced-displacement-2016.html

Este artículo recuenta la respuesta poco entusiasta del Reino Unido para la reciente crisis de refugiados que Europa enfrenta actualmente y revisa la aproximación de los británicos de proporcionar un santuario desde sus orígenes ideológicos e históricos, hasta sus promulgaciones políticas entre los años 1905 y 2016. Esa aproximación resuena con las tensiones profundas que están en el tema de la inmigración dentro del estado nación y la separación intensa del santuario y sus iniciativas humanitarias. Yuxtaponemos la participación del gobierno del Reino Unido en la crisis de refugiados con su 'tradición humanitaria' en la que el Reino Unido se ha idealizado como un santuario para los que han escapado la persecución, la tortura o el conflicto. El ideal histórico del refugiado ha sido cuestionado con numerosas políticas de inmigración y asilo, así como una seguridad incrementada de los controles de frontera en respuesta al contexto político cambiante desde 1905. Argumentamos que 'santuario' es un componente reducido y controvertido de su calidad humanitaria de hoy en día que involucra una seguridad y políticas de asilo incrementadas con controles migratorios más estrictos. Esquematizamos la posición dura y restrictiva del Reino Unido hacia el refugiado y el solicitante de asilo a través de una serie de políticas del Aliens Act en 1905 al Dubs Amendment de 2016 que buscan deslegitimar a los refugiados, establecer barreras más firmes en 
contra de su ingreso y tratarlos como 'migrantes' económicos y figuras sospechosas en un mundo post 11 de septiembre.

Palabras Clave: Política de Inmigración, Refugio, Refugiado, Asilo, Reino Unido, Gran Bretaña, Santuario, Control de Fronteras, Calidad Humanitaria.

本文追踪了英国对近期欧洲面临难民危机的迟缓回应; 并从思想起 源和历史起源，到1905-2016年间制定的政策，评论了不列颠为提供 避难所而采取的措施。该措施 (使人) 联想到英国移民问题所引起 的严重紧张局势, 以及避难所被移除在人道主义倡议之外。作者将 英国政府参与移民危机一事, 和其”人道主义传统”进行比较, 后者 将不列颠理想化为避难所, 为逃离迫害、折磨和冲突的那部分人提 供庇护。自1905年政治背景不断变化后，这一历史性的避难所形象 便一直受到诸多挑战一包括移民政策、避难相关政策, 以及边境管 制安全化的不断提升。作者主张, “避难所”是现如今人道主义中被 削弱且饱受争议的部分, 它包括安全化提升和严格的移民管控避难 政策。从1905年通过的《外国人法》到2016年通过的《杜布斯修正 案》，这一系列政策试图取消难民的合法地位、制定更严格的入境 障碍、并将难民描述为经济”移民”和 911 事件后的嫌疑人物。通过 这一系列政策，本文追踪了英国对待难民和寻求避难者（asylum seeker) 时的严苛态度。

关键词: 移民政策, 避难所, 难民, 庇护, 英国, 不列颠, 欧洲, 庇护所, 边境 管制, 人道主义.

The recent refugee crisis confronting Europe has thrown up various challenges, both for the European Union and its member states, and is likely to continue with an estimated one million refugees heading for Libya and Europe from countries across Africa (Wintour 2017). For the United Kingdom, like other countries, providing asylum to refugees and entry to migrants have become national issues coloring internal debates and bringing its legal and social obligations as part of the European Union or the European community into question. The 2016 referendum on the European Union underscored the issue of immigration as an epoch-defining political issue (Wadsworth et al. 2016), one which both the "remain" and "exit" camps seized on as a means to rally popular opinion and support for their respective manifestos. In the process, these have shed an introspective light on the U.K.'s contemporary policies and notions of humanitarian refuge with their roots in ancient religious practices of sanctuary.

Such introspection comes at a critical juncture as the world faces its "biggest refugee and displacement crisis of our time" (Ban Ki Moon, cited in United Nations High Commissioner for Refugees [UNHCR] 2016, 4) with forced migration reaching record post-war levels. In 2015, the numbers had risen to 65.3 million people worldwide, representing an increase of 10 percent from the previous year. An escalation in political conflict and religious 
persecution from Syria, Eritrea, and Somalia to Iraq and Afghanistan have led to over a million people - or a four-fold increase from the previous year-crossing into Europe in search of sanctuary, presenting the European continent with its biggest refugee-based humanitarian crisis since World War II (UNHCR 2016).

In the first half of the twentieth century, international refugee law was country specific but after World War II and within the context of the new United Nations (UN), the present system for the protection of refugees as a universal system came into existence. It comprised the UNHCR formed in 1950 and the Convention relating to the Status of Refugees, the 1951 Convention. These defined the refugee and the rights attached to that status. According to the 1951 Convention,

the term "refugee" shall apply to any person who... as a result of events occurring before 1 January 1951 and owing to well-founded fear of being persecuted for reasons of race, religion, nationality, membership of a particular social group or political opinion, is outside the country of his nationality and is unable or, owing to such fear, is unwilling to avail himself of the protection of that country; or who, not having a nationality and being outside the country of his former habitual residence as a result of such events, is unable or, owing to such fear, is unwilling to return to it. ${ }^{1}$

The universal scope of the Convention was limited by both space and temporality wherein the recognition of refugee status is underpinned only in relation to events that occurred in Europe and before January 1, 1951. The definition of the refugee was expanded to include anyone who, if expelled, would face a real risk of exposure "to torture, or inhuman or degrading treatment or punishment" with the adoption of the 1967 Protocol Relating to the Status of Refugees. The UN Refugee Convention 1951 excluded those suspected as war criminals and terrorists as warranting protection. However, Article 3 of the European Convention on Human Rights (ECHR), incorporated into U.K. law through the Human Rights Act of 1998, nevertheless prohibited their deportation if in the event they faced a real risk of degrading or inhumane treatment (Gibney 2011). The main distinction between refugees and asylum seekers is in terms of security of residence. Once an asylum seeker is accepted as a refugee, she is generally free from the threat of removal and with the issue of a refugee passport by the Home Office, she could leave and return to Britain and have the right to have her family join her.

Britain's notion of a humanitarian ethic toward the persecuted and the provision of refuge predates contemporary international human rights law or international refugee law. In the nineteenth century, the sense of a distinctive British

\footnotetext{
${ }^{1}$ See Article 1(A)(2) of the 2016 Convention at http://www.unhcr.org/3b66c2aa10.html
} 
tradition of humanitarian refuge emerged out of older religious practices of sanctuary, which enabled the nation to imagine itself as morally superior, ennobled, and more enlightened than its European counterparts (Rabben 2011; Shaw 2015). The tradition emerged in propitious circumstances of open borders where people were generally able to come and go as they pleased with these informal policies distinguishing Britain from its European counterparts. However, with mass forced migration and the loss of empire in the twentieth century, borders became increasingly politicized, and control over who could enter marked an overt assertion of sovereign power and a measure of the effectiveness, or otherwise, of government policies. As such, the U.K.'s historic humanitarian ideal of being a sanctuary for the persecuted became uncoupled from its open borders approach. The 1905 Aliens Act not only reinstated border controls, it also for the first time defined refuge in British law and created legal protocols for asylum and as such formalized the British tradition of humanitarian refuge (Bashford and McAdam 2014). In reality, the Act marked the beginning of a moral and material contestation of this ideal over the next 120 years as issues of immigration, border control, membership of the European Union, and securitization issues would test its commitment to the romantic myth of being a safe haven for the displaced and persecuted, leading to an increased racialization, stigmatization, and fear of the Other.

We draw from a strong body of literature on the ideal and historic practices of sanctuary and humanitarian refuge in the United Kingdom and, in particular, the role of the state both in terms of its rhetoric and material enactments in terms of policy provisions as well as diplomatic gestures in times of war and conflict (see Rabben 2011; Shaw 2015). This article traces the demise of the ideal through a succession of increasingly restrictive policies on immigration and asylum. Today, with a dramatic rise in numbers of refugees displaced due to forced migration, particularly with the unresolved situation of refugees in Calais and in the Mediterranean, the U.K.'s historic-romantic and moral position of being a safe haven remains a myth. The U.K.'s tepid response to the refugee crisis bears the teeth marks of ever more restrictive asylum and refugee policies over the years. Key mechanisms for contracting humanitarian refuge have seen the coalescing of asylum and refuge with stringent immigration policies. This has led to the stigmatizing of asylum seekers as fraudulent or opportunistic and suspect figures attracted to the "generous" U.K. welfare system.

The attitudes toward immigration have, over the years, been shaped by the U.K.'s relationship with its former colonies and equally its membership of the European Union that has witnessed an influx of European migrants at different points in time. The role of subsequent governments in reducing the provisions for asylum seekers both in their immediate access to legal assistance and welfare reflects the increased subsuming of refuge under immigration control measures within the United Kingdom. In the contemporary context, against the austerity politics of the Conservative government, the refugee is portrayed as both a threat to national security and contributing to the shortage of housing and 
welfare at large. As such, the control of border space is tightly entwined with the domestic politics of disaffection. The U.K.'s response to the humanitarian crisis in Calais and the Mediterranean has been through a distant or nonproximate approach by increasing securitization at the borders and outsourcing border controls and aid to other countries or verifying the authenticity of their claims of persecution at the countries of origin rather than in Europe. Today, immigration policy and immigration controls are seen as vital to electoral success; and in tandem successive governments since the turn of the 1900s have cumulatively restricted their obligations to the Other as a means to assuage domestic politics.

With the demise of the empire, withdrawal of rights and obligations to the former colonies, the formation of the European Union, and the recent referendum in Britain to leave the European Union, the notions of refuge and political sanctuary remain an area of intense scrutiny and fear, welded to the politics of welfare, employment, racialization of immigration, British identity, and state sovereignty. It was a pivotal issue in the Brexit referendum in 2016 where the decision to leave the European Union was in many ways framed as a means for Britain to regain control over its borders. The provision of asylum, while integral to the imagination of the nation as humane and compassionate, has over time been mediated by the politics of race and the nation space; prescribing who is admitted and who is cast out, and equally how the entrants may be a threat to both the coffers and values of the nation state. The different waves of the refugee crisis have been a testing ground for the British historical ideal of providing sanctuary. The refugee crisis in Calais and the Mediterranean became a theater for this contracted humanitarianism which has been ongoing since the turn of the twentieth century. The refuge element, which was historically conjoined to Britain's humanitarianism, became rapidly mediated and uncoupled particularly after World War II.

The U.K.'s response to the present refugee crisis needs to be politically and historically contextualized where the figure of the refugee has been reconstituted through policy enactments over time. This article examines the British government's engagement with the latest refugee crisis against its "humanitarian tradition" of providing asylum or sanctuary to those from conflict zones or whose lives are deemed to be at risk. In assessing how the United Kingdom responds to the present forced migration and refugee crisis, this article traces the humanitarian "tradition" in British history, providing an historic overview to assess the policies enacted by the United Kingdom to deal with the refugee within the ambit of immigration and asylum policies. These cumulative enactments and legislation were intended to retain the provision of sanctuary while regulating the processes of admission and deterrence provide a context in which to analyze the present refugee crises and to locate Britain's "nonproximate" or externalization approach where there is an outsourcing of the crisis (i.e., in processing asylum applications, detention, repatriation, and border patrol) to external partners far away from its border space. We argue 
that the figure of the present-day refugee is a historically mediated entity conceived through the romantic myth of safe sanctuary. In reality refugees and asylum seekers are bodies which are constantly disciplined and curtailed. They remain indexical symbols of Britain's historic tradition of humanitarianism but are products of years of policies which commit to a politics of attrition of both the conception of her as human and her rights.

\section{Ancient, European, and International Contexts}

The "humanitarian gesture" as the "will to alleviate suffering" is prevalent across time and space in most societies, cultures, and religions (Davey, Borton, and Foley 2013). The Western origins can be traced to the sanctuary practices of the ancient world, which offered refuge to those fleeing for their lives in the name of the gods and in sacred spaces. ${ }^{2}$ These practices emerged through a combination of pity for those whose plight one could share tomorrow and fear that failure to provide sanctuary could incur the wrath of the gods.

The Romans in the fourth-century AD and then the Catholic church fused classical and Judeo-Christian practices into a codification of practices, and a common understanding of sanctuary suffused through their network across Europe for over 1,000 years (Rabben 2011). By the Middle Ages, sanctuary had become one of the most important and powerful institutions in medieval Europe (Shoemaker 2011b), but codification also brought exclusion. While the Greeks offered sanctuary to runaway slaves, political activists, and fugitives from justice (Gorman 1994), Roman and Papal codes excluded Jews, heretics, and apostates (Rabben 2011). In medieval Europe, fugitives were at the mercy of local bishops who had the discretion to intercede on their behalf and offer sanctuary (Shoemaker 2011b). By the seventeenth century, the associated power and discretionary abuses had brought the practices into disrepute and the churches began dismantling their codes (Shoemaker 2011) and the nation state increasingly assumed responsibility for the provision of refuge within its borders. ${ }^{3}$ The religious practices of sanctuary were replaced by secular practices of humanitarian

\footnotetext{
${ }^{2}$ The English word sanctuary is derived from the Latin sanctuarium meaning "sacred place, shrine" and the Hebrew sanctum (Online Dictionary of Etymology; https://www.etymonline.com/word/ sanctuary). The related word, asylum, meaning a "place of refuge, sanctuary," is from the Greek asylon meaning "refuge, fenced territory." Literally it meant an "inviolable place," and from 1712, it meant "inviolable shelter, protection from pursuit or arrest."

${ }^{3}$ Sanctuary as a religious practice continued in some of the Mediterranean states until the nineteenth century. It was revived by the Papacy in World War II when the Vatican, as a city state, provided exit routes first for Jews and then Nazi fugitives at the end of the war. The religious practices have also been revived in the Sans Papiers Movement in France in which some of the churches in the late 1990s offered refuge to the undocumented migrants (Freedman 2008) and the Sanctuary movement in the United States, a religious and political campaign in the 1980s to provide humanitarian refuge for Central American refugees fleeing civil conflict. The movement was a form of resistance against increasingly restrictive immigration policies that made obtaining asylum more difficult.
} 
refuge, driven by an imperative to alleviate suffering rather than out of fear for the wrath of God in failing to offer sanctuary, and the discretion of ministers replaced that of the bishops. The legacies of the Roman and medieval practices continued in a common, romanticized notion of sanctuary but, with the shift in responsibility to the state from the seventeenth century, the "international" dimension of the practices fragmented and differentiated around national imperatives. Fragmentation made possible the emergence of a distinctive British tradition in the hiatus between the decline of religious practices and the reinstatement of border controls in the nineteenth century (Shaw 2015).

War, ethnic cleansing, and genocide in the twentieth century exposed the humanitarian consequences of fragmentation and discretion in practices of refuge. Europe was horrified by the unprecedented levels of displacement and suffering, and the figure of the refugee emerged as an international subject in need of protection (Cabanes 2014; Panayi and Virdee 2011). After World War I, a new moral imperative appeared for the international codification of humanitarian refuge and its practices. While those displaced by war, conflict and persecution had long been known as refugees, it was "not self-evident who could be formally classified as a refugee" or what system might provide for refuge (Sallinen 2013, 1). The work started by the League of Nations was interrupted by the Second World War and resumed again under the aegis of the UN. The conventions and protocols adopted between 1948 and 1961 encoded the definition and rights of the refugee into contemporary international agreements that have increasingly been written into European Union and British law. Not only is Britain a signatory of these international agreements, the involvement of its lawyers in the drafting of the UN ones played a key role in the romanticized imagining of a distinctive British tradition of humanitarianism (David Milliband, quoted in Borger 2015). The international agreements revived much older understandings of the provision of a refuge for those fleeing for their lives.

The primary concern in Europe after the war was the potential power of states to abuse citizens. ECHR (1953) evolved to address this backed by the legal power of the Strasbourg Court whose rulings are binding. ${ }^{4}$ The initial focus on the citizen and the right of the sovereign state to determine who might cross its borders meant that the ECHR was slow to consider cases involving refugees $^{5}$ and to a large extent it was some of the other European agreements that

\footnotetext{
${ }^{4}$ While the European Convention and the Strasbourg Court have privileged the citizen and the right of the sovereign state to determine who may enter its borders, the American counterparts (American Convention on Human Rights and the Inter-American Court of Human Rights) have prioritized the " "plight of migrants' such as the refugee in search of asylum and the foreigner born without a nationality" (Dembour 2015, 22).

${ }^{5}$ Dembour $(2015,23)$ cites the East Asians' case brought after the British government in 1968 virtually overnight introduced legislation that stripped Asian holders of British passports, being expelled from Kenya, the right to live in Britain. The case was not heard by the court but a confidential European Commission in 1973, which concluded that the legislation was racially motivated and contravened the European Convention (Article 3) which prohibits inhuman or degrading treatment.
} 
shaped the development of European Union law on border controls, immigration, and asylum. The Schengen Agreement (1995) allowed for the free movement of people, trade, and capital between signatory states, and the Amsterdam Treaty (1997) laid out the intention to develop common immigration and asylum policies with a view to harmonizing both (Costello and Han$\operatorname{cox} 2014){ }^{6}$

Britain has consistently maintained a position of exceptionalism, opting out of European Union agreements on free movement, asylum and immigration, and the removal of illegal migrants. However, successive governments have opted for measures to strengthen border controls, policing, and securitization including the right of states to fine companies that carry undocumented stowaways into the country. Britain also opted into directives on the Dublin Regulations which obliges an application for asylum to be made in the first country of entry to the European Union ${ }^{7}$ and on the removal of irregular migrants to third countries. Much of the legislative activity explored in our analysis incorporates some of these measures into British law and the increasing restrictions and barriers to entry.

Underlying this bewildering array of opt-ins and opt-outs under the European Union, there has been a clear rationale behind British selectivity in choosing those policies that "reinforce rather than overturn established patterns" in domestic policy (Geddes 2005, 723), accepting the more coercive elements that restrict entry and strengthen border controls while opting out of more protective measures-for instance, on family reunion (Fletcher 2009, 81). Selectivity has enabled Britain in the contemporary refugee crisis to refuse its "quota" of asylum seekers already in the European Union. Under the Dublin Regulations, which require refugees to apply for asylum in the first country they enter, the United Kingdom can return refugees to whichever European Union country they traveled through to reach Britain. ${ }^{8}$ The opt-out of the Schengen Agreement also enables Britain's external border controls to be sited on the FrenchBelgium side of the English Channel.

Overall, the opt-ins and opt-outs have meant there has been some convergence but also much leeway between Britain and other European Union states

\footnotetext{
${ }^{6}$ The treaties, agreements, and protocols have gradually been writing the Refugee Convention into European Union law (Costello and Hancox 2014).

${ }^{7}$ The Dublin Regulations have been constantly revised. Dublin III provided more opportunities for family members to request a transfer to other member states in order to be together and have their claims considered in the same country. The Regulations also privileged the "best interests" of the child and "respect for family life" and made special provision for unaccompanied minors. UNHCR, in response to the European Union's review of Dublin III, called for a more "proactive and efficient use" of the Articles on family unity, unaccompanied minors, and dependants (Refugee Council 2015).

${ }^{8}$ Dublin Regulations, a "safe third country," available online at https://righttoremain.org.uk/toolkit/dublin.html
} 
in practices of dispersal, detention, and deportation of asylum seekers (Costello and Hancox 2014) as well as in the forced co-opting of industry to assist in the detection of stowaways. ${ }^{9}$ Notwithstanding Britain's exceptionalism and European Union attempts at harmonizing border controls, when it comes to migration and asylum, states have remained "the most influential" in determining policies on entry, settlement, and integration of asylum seekers and refugees (Kofman 2002).

\section{Humanitarianism, Humanitarian Refuge, and a "Distinctive" British Tradition}

The term "humanitarian," while difficult to date, came into common parlance in the early nineteenth century to refer to a range of activities intended to protect and improve humanity (Barnett 2011). Although the "humanitarian gesture" as the "will to alleviate suffering" is an ancient one and global in that it can be found in most societies, cultures, and religions (Davey, Borton, and Foley 2013), it has nevertheless been presented as embodying the values of an "Enlightened West" (Egeland 2011). Humanitarianism as rooted in a moral imperative to act emerged out of nineteenth-century ideals circulating in Europe; however, distinctive traditions were shaped by historical and political conditions in different countries (Barnett and Weiss 2011). In the twentieth century, humanitarian action has become most commonly associated with the activities of nongovernmental organizations (NGOs) and civil society. Yet there is also a sizeable literature on the long history of state involvement in humanitarian interventions, through diplomacy or force, in foreign states (see Simms and Trim 2011) to alleviate suffering and in the provision of humanitarian refuge (see Shaw 2015). Our focus is on the latter.

During the middle to late nineteenth century, a distinctive British tradition of offering refuge to strangers emerged (Shaw 2015), and by the mid-nineteenth century, the meaning of the term had expanded to include anyone who fled persecution for religious or political reasons (Bashford and McAdam 2014; Shaw 2015). Despite the U.K.'s secular national identity in modern history, its conception of humanitarian refuge can be traced back to the religious meaning of sanctuary rooted in Judeo-Christian traditions. As religious practices gave way to secular ones, the imagination of refuge as a vital aspect of the British psyche and tradition remained through time (Borger 2015; Shaw 2015) and became a

\footnotetext{
${ }^{9}$ Post-Brexit, the British government has committed to retain all existing European Union law already adopted and to reviewing it over time. Given Britain's highly selective approach to border controls, asylum, and immigration as a member of the European Union and the complexity of the Irish border, it is unclear what is likely to change. There has been debate in France about pushing the border controls back to Britain but whether that is practicable, given the Eurotunnel, is open to question. The policy situation is too unstable to be able to speculate at this stage.
} 
resonant theme in the collective imagination of the nation and that of the empire.

A primary aspect of humanitarianism is the response to crisis or emergencies where sudden and unforeseen events demand urgent action to alleviate suffering and save the lives of large numbers of people. There are also ongoing crises that call for direct intervention to arrest a deteriorating condition. The core principles derived from the humanitarian ideals and their underpinning human values of empathy for humanity at large provided a means to imagine and project Britain as having a higher moral imperative, as being more enlightened and evolved than its more despotic European counterparts (Shaw 2015). The notions of sanctuary and humanitarian refuge, while rooted in mythological and religious traditions in the nineteenth century, enacted the provision of refuge through the binary of the host and guest - inscribing power, moral superiority, and patronage to the act of refuge. The modern-day conceptions of humanitarianism emerging in the mid-nineteenth century through Enlightenment discourses lobbied for the conjoining of concerted action and moral responsibility with human compassion. In Victorian Britain, theological ideas, enlightenment ideals, debates around antislavery, and administration of the empire dialectically coalesced with the U.K.'s moral imperative for the nation to be a safe space or refuge for the persecuted (Shaw 2015; Skinner and Lester 2012).

The U.K.'s notion of humanitarianism, particularly the provision of asylum to the dispossessed Other, has been tested over time in history. From the heyday of the empire to the present day, the notion of giving humanitarian refuge has been an arena that has witnessed a vast array of policy enactments to contain and control the influx of refugees and asylum seekers. As such, the "refugee system" represents the policy domain that determines the status of refugee claimants and assists in the settlement of those individuals granted asylum (Laumann and Knoke 1987). It encompasses the formation and implementation of policies and practices that relate to the rights of individuals to claim asylum, the procedures whereby claimants are awarded asylum, and the support provided to claimants and refugees. Over the years, the retention of the clause to provide humanitarian refuge to the displaced or those fleeing from persecution has been fiercely scrutinized, debated, and protected in parliament and in the media. The cumulative policy enactments since the turn of the century throw light onto the dissonance between ideals and policies designed to curb immigration and asylum.

The imperative to restrict refuge - despite retaining it as a definitive element of its humanitarianism-gained momentum and impetus at different points over time, reflecting global politics, domestic opposition to people coming into the United Kingdom, and Britain's ambition to carve a moral role for itself after the demise of the empire. Asylum was reframed as a "problem" and successive British governments have chafed under their internal obligations to refugees as migration became an election issue, the number of asylum applications mounted, backlogs grew, and debates shifted from issues of refuge to the cost of dealing with asylum seekers. Terrorism added a potent element to the mix. 
The United Kingdom over time tightened asylum procedures making it harder to obtain the legal status of a refugee and easier for the state to deport unsuccessful applicants.

Successive governments since then have invested heavily in tighter security at continental ports and the resistance to taking in more migrants is thus part of a long-term contraction in humanitarianism toward asylum seekers. Two of the most important conventions relating to refugees and asylum seekers-the 1951 Geneva Convention and the ECHR - only became part of British domestic law in 2000 (Schuster and Solomos 2001, 1). Until the 1993 Asylum and Immigration Appeals Act, the process of granting refugee status or asylum was not regulated by primary legislation but under procedural rules which gave the government a high degree of discretion and flexibility over who would be admitted or refused. The convention as such was a malleable instrument that was interpreted to fit the needs and interests of the government of the day (Schuster and Solomos 1999). These enactments to restrict asylum are divided into six phases in our analysis, and the primary modes of restriction are the main points of our focus in this trajectory.

\section{6-1905: Open Borders}

The United Kingdom in the nineteenth century followed the religious principle of providing sanctuary in sacred sites to anyone who needed it. This policy was facilitated by an 80-year lapse of the 1836 Aliens Act and the passage of the new Aliens Act in 1905. During this period, there were virtually no border controls, no laws distinguishing refugees, and as such any foreigner could enter Britain freely, and refugees were entitled to relief from the Poor Law, ${ }^{10}$ or the workhouse (Shaw 2015). The normative assumption that a dignified existence should be accorded to the refugee, encompassing political and humanitarian sympathy as well as a physical sanctuary, became part of the common cause in advancing liberty worldwide (Barnett 2011; Barnett and Weiss 2011; Shaw 2015). During a century of revolution, while other relatively free states such as Belgium, France, and Switzerland ${ }^{11}$ extradited political and religious refugees who were seen as politically inconvenient or embarrassing and introduced increasing restrictive laws that made European countries "increasingly inhospitable to "refugees"" (Rabben 2011, 61), Britain resisted the trend to follow suit (Shaw 2015). Instead, she allowed the politically and socially displaced,

\footnotetext{
${ }^{10}$ From Elizabethan times, the English welfare system was based on the Poor Law originally administered and financed by church parishes and overseen by the courts, but a series of reforms from the 1830s meant that a central Poor Law bureaucracy was established. The definition of who was an "outsider" changed from those who were outside the parish to those who were immigrants (Feldman 2006), particularly after the 1905 Act.

${ }^{11}$ Britain replaced Switzerland in the European firmament of humanitarian refuge. The Swiss government viewed asylum as a "humanitarian concession" that it could revoke or refuse but when the country attracted revolutionaries, Switzerland expelled them and England became the "most significant asylum-granting country" in Europe (Rabben 2011, 61).
} 
including Russian anarchists, Hungarian nationalists, French émigrés as well as Catholics, Protestants, and Jews to enter and remain. There was popular public commitment to the notion that refugees were entitled to more than a temporary stay of relief but also a dignified existence (Shaw 2015).

European moral philosophies in the Enlightenment period played an important role in shaping the ideas of humanitarianism. Immanuel Kant expanded on the idea that all human beings should be treated as free and equal by adding a categorical imperative or unbreakable moral rule that "every rational being" should be treated as an end in themselves and not a means to an end (Stoecker 2011). This constituted a powerful ethical critique of slavery and contributed to the emergence of the antislavery movement, widely seen as a precursor to a form of humanitarianism which seeks to address the structural causes of suffering (Barnett and Weiss 2011). Social reformists of the nineteenth century and human rights advocates of the twentieth century drew on these ideas that were institutionalized in the 1948 UN Declaration of Human Rights (Barnett and Weiss 2011). Kant's cosmopolitan law was also influential as it emphasized the status of individuals as human beings in their dealings with states of which they are not citizens, premising their "right to hospitality" (Kleingeld 1998).

\section{5-60: Retention of Humanitarian Refuge despite Unease}

British willingness to offer refuge began shifting between 1880 and 1914 with the forced migration of Jews fleeing religious persecution in Eastern Europe when about 150,000 settled in Britain (Bashford and McAdam 2014). It gave rise to debates concerning how to regulate the entry and impact of large numbers of refugees and the fundamental questions concerning who Britain wanted and did not want to admit. The Aliens Act of 1905 defined for the first time in British law the notion of the "undesirable immigrant" as "criminal aliens, the destitute, the ill or the infirm" who would place a burden on the Poor Law institutions and the emerging health and welfare systems (Bashford and McAdam 2014). ${ }^{12}$ Although the Bill did not specify Jews, the debates concerning it, particularly by Members of Parliament in the East End of London where many of the Ashkenazi Jewry sought refuge, were anti-Semitic centering on stereotypes about diseased and criminal "aliens" who had moved into depressed areas of London (Bashford and McAdam 2014). The debates leading up to the Aliens Act of 1905, infused by xenophobic and anti-Semitic discourses, produced legislation restricting entry and demarcating those worthy and not worthy of asylum by distinguishing between those able to support themselves and

\footnotetext{
${ }^{12}$ States and self-governing colonies around the world from America to South Africa and Australia had from the 1880 s begun to legislate against entry by "undesirable immigrants" but the target was different. In Britain, the concern was to restrict the entry of destitute Jews fleeing repression in Russia and Eastern Europe. In these other countries and colonies, the intention was to restrict Chinese migrants attracted to the gold rushes (Bashford and McAdam 2014). The principle, though, was the beginnings of immigration systems that differentiated between the wanted and the unwanted.
} 
those perceived as likely to "contaminate" the polity through poverty or disease (Bashford and McAdam 2014; Kushner 2003).

Opponents of the Aliens Act of 1905 felt it undermined Britain's distinctive identity as a refuge from tyranny of persecution on religious or political grounds. In response to these strands of debates, the Act retained the right to asylum, framing it as an individual right of entry for those fleeing political or religious persecution. In so doing, the Act for the first time enshrined in law the category of the "refugee," defined as those at risk of persecution for political or religious reasons (Bashford and McAdam 2014). ${ }^{13}$ The 1905 Aliens Act made a seminal connection between immigration and welfare; in particular, the concept of "recourse to public funds" was introduced (Miles and Cleary 1993). This was to remain a contentious aspect of policy making for years to come. The humanitarian ideal of offering refuge remained a key aspect of the British psyche in this period and can in large measure be traced to Britain's role as an empire and the Queen's role as a protector of citizens - under this vast empire - and acting in their best interest.

\section{0-90: The Commonwealth and the Politics of Race}

Since 1945, there has been a tendency to equate the "immigrant" with black people and ethnic minorities in popular discourse whether they have the formal designation of migrants or have the legal status of refugee (Cohen 1994; Miles 1989; Miles and Cleary 1993). In tandem, the admission of refugees has been influenced by the conjoining of "race" with immigration in the United Kingdom. With the breakup of the empire and self-rule in former colonies from the 1950s and 1960s, the United Kingdom sought to reduce its residual obligations with former colonies or in according them special rights.

During this period, a raft of policies toward former colonies and subjects delineated a racialized approach to immigration (i.e., the Commonwealth Act of 1962 and 1968, and the Immigration Act of 1971), restricted entry, and identified "undesirable" elements based on racial grounds while retaining the right to asylum. These restrictions culminated in the 1968 law which specifically targeted blacks and Asians facing increased discrimination in newly liberated states (Hansen 1999, 2003). In 1968, an Act rushed through parliament in just three days left some 200,000 Asians expelled from Kenya stateless after Britain and India refused entry. In theory, they should have been able to claim the protection of the British state. However, rather than honor international obligations under the 1951 Convention or their duties to British citizens, the British government chose to withdraw the right of entry and settlement from that group by introducing the concept of "patriality" in the 1968 Commonwealth Immigrants Act: "any citizen of Britain or its colonies who held a passport

\footnotetext{
${ }^{13}$ The codifying of the individual right to asylum from persecution was "unique" and predates the later international treaties (Bashford and McAdam 2014).
} 
issued by the British government would be subject to immigration control unless they or at least one parent or grandparent was born, adopted, naturalised or registered in Britain as a citizen of Britain or its colonies" (Solomos 1993, $66)$.

The immigration Acts between 1962 and 1988 not only eroded rights of entry to Asian and black people but also curtailed the citizenship rights of former colonial subjects bringing virtually all primary migration to an end (Bloch 2000). It curtailed the entry for settlement into the United Kingdom to family reunion cases and to refugees and asylum seekers. The Immigration Act of 1988 ended the right to automatic entry of dependants of Commonwealth citizens who settled before 1973, marking the end of much of the immigration from Commonwealth countries. The Act also specified that families could only be united if there was no recourse to public funds, solidifying a link which had already been made earlier in the Aliens Act of 1905 (Bloch 2000; Miles and Cleary 1993). Further reforms curtailing welfare have been justified under the basis that these are necessary to deter those who might come to Britain on account of the perceptions of generous welfare provisions (Düvell and Jordan 2002).

The Immigration Act of 1971 deepened the racialization of immigration by creating an exclusionary aspect to British citizenship based on the concept of "patrials" and "nonpatrials" (Goulbourne 1998). This meant millions of white Commonwealth citizens could, in theory, enter Britain under the patriality clause while almost all non-white Commonwealth citizens were excluded by "racially defined categories" (Spencer 1997, 143). This racial delineation was further augmented by the National Act of 1981 that abolished citizenship through place of birth (or jus soli) and replaced it with citizenship through descent or jus sanguinis. This had the effect of excluding children born in Britain to Commonwealth migrants from immediate entitlement to citizenship. It further created three categories of British citizenship, two of which (i.e., British Overseas Citizenship and Citizenship of British Dependant Territories) were not entitled to the right of abode.

The introduction of visas in the 1980s as a response to outbreaks of conflict affected both asylum seekers and people seeking family reunification (Cohen 1994; Morris 1998) and had an impact on Commonwealth citizens. In 1985, for example, visa requirements were introduced for Sri Lankan nationals when there was an increase in the numbers of asylum applicants from Sri Lanka. The policy of restricting entry to the United Kingdom was reinforced by the Carriers' Liability Act 1987 where heavy fines were imposed on all carriers transporting people to the United Kingdom without appropriate documentation. It placed the onus on airline and shipping companies to detect anyone traveling with false and therefore illegal documents.

\section{0-2000: Firming Immigration Controls}

The ongoing curbs on migration since the 1960s and the influx of large numbers of those forcibly displaced by conflict in the Balkans, Afghanistan, 
and Iraq meant that asylum seekers were the main category of primary migrants during the 1990s. Since then, there has been a proliferation of laws intended to make the attaining of asylum and the lives of those seeking it in the United Kingdom more uncomfortable (Gibney 2004) both in terms of entry and in the area of welfare entitlements. It mirrored and prolonged the stance taken with the East African Asians projecting haste in its endeavor to bar the influx of refugees. The cross-party consensus was of an existing asylum system that was inadequate in dealing with refugees, prompting calls for reform of the system (Mulvey 2010). The refugee issue began to fall increasingly under immigration control rather than the larger ambit of immigration policy (Kaye 1994).

The 1993 Asylum and Immigration Appeals Act was promulgated into U.K. law as the first piece of primary legislation dealing specifically with asylum since the 1905 Aliens Act. It incorporated the Refugee Convention into British law but was shaped more by attempts to deter those seeking refugee status in the United Kingdom than to help them (see Bashford and McAdam 2014; Keyes 2004). Increased restrictionism in the reception and integration of those who do gain entry became the dominant characteristic of the refugee policy framework (Zetter, Griffiths, and Sigona 2005, 171). The 1993 Act was advanced as a means to speed up the processing of asylum applications, but in reality the Act imposed harsh new measures on asylum seekers intending to deter them from arriving in the United Kingdom (Macdonald 1993). These included the extension of the Carrier's Liability Act to make airlines responsible for ensuring transit visas to avoid transit passengers disembarking in the United Kingdom and claiming asylum. Compulsory fingerprinting was introduced along with the provision that asylum seekers had to appeal against unfavorable decisions within 48 hours, and the statutory duty of local authorities to provide social housing for asylum seekers if they had any form of temporary accommodation was curtailed (Sales 2002).

The 1993 Act, although designed to reduce the number of people entering the United Kingdom as refugees or asylum seekers, nevertheless sought to incorporate the 1951 Convention and the introduction of a right of appeal (Morris 2009). In 1998, the Human Rights Act was passed, which specifies that no laws should be passed that contravene the ECHR and was critical in giving British judges the opportunity to rule on the convention in British courts. ${ }^{14}$ Prior to this, human rights cases that fell under European Union law when all avenues had been exhausted in Britain, had to be heard in the ECHR and even there the numbers of asylum-related cases have been relatively few and only a handful have been successful (Dembour 2015, 1). The tightening of immigration controls was deemed as necessary for good race relations (Minderhoud

\footnotetext{
${ }^{14}$ Britain had been the first to ratify the ECHR in 1951 (Simpson 2004, 2, cited in Morris 2009, 222) and was already committed to the principles but the passing of the 1998 Human Rights Act allowed British judges to rule on cases contravening the Convention in British courts (Morris 2009).
} 
1999; Spencer 1997). Just two years later in November 1995, the government introduced the Asylum and Immigration Act of 1996.

The 1996 legislation curtailed welfare entitlements for some asylum seekers by creating two categories of entitlement (Morris 2009). Asylum seekers who had applied for asylum at the port of entry would be eligible for 90 percent of the social security benefit income support. Conversely, those who applied in the United Kingdom and those who were appealing against a Home Office decision on their case were to be excluded from benefits although there were provisions made for in-kind support from local authorities. The welfare provision in the United Kingdom was seen as attracting economic migrants. Asylum seekers are not allowed to apply for a work permit until they have been resident for six months, which means that some have no access to social security benefits and no legal entitlement to work on their arrival to Britain. Much of the responsibility for supporting destitute asylum seekers fell on local authorities (Kaye 1994), who have a statutory duty to provide subsistence support for single asylum seekers under the 1948 National Assistance Act and asylum-seeking families under the 1989 Children Act. Local authorities are not allowed to provide cash assistance to in-country asylum applicants under the 1948 Act but instead offer supermarket vouchers and assistance "in kind," such as food parcels and clothes (Sales 2002).

The 1996 Act also included a clause relating to employment. Employers found to have hired someone without the proper documentation would be subjected to a penalty fine (Webber 2008). The 1996 Act saw the creation of the "White List" of countries that were deemed to be safe. ${ }^{15}$ Applicants from these countries were to be fast-tracked through the appeals process. This contravenes the spirit of the 1951 UN Convention on the Status of Refugees as the nationality of an asylum applicant should not affect the determination process. The White List was later abolished by the Labour government.

While it was acknowledged that Britain had legal and humanitarian obligations to "genuine" asylum seekers under the 1951 Geneva Convention, there was a consensus that "bogus" asylum seekers should be prevented from exploiting the system (Kaye 1994). The "bogus" asylum applicant is a recurrent discourse in U.K. debates concerning immigration (Maughan 2010). Debates surrounding the Asylum and Immigration Bill of 1996 were very similar to those that had preceded the 1993 legislation converging around the dichotomy between genuine and bogus asylum seekers and the need to stop the abuse of

\footnotetext{
${ }^{15}$ The White List identified countries the Home Office deemed to be "generally safe" and presenting no "serious" risk of persecution (Schuster and Solomos 2001). The list allowed the government to presume that asylum applications from those countries were likely to be unfounded therefore could be fast-tracked and rejected unless the applicant could produce evidence to refute that (Bolton 2003). The development of a White List was first adopted by European Union home affairs ministers in 1992 (Migration News 1995) and strengthened in the 1996 Asylum and Immigration Act (Keyes 2004).
} 
the system that occurred as a result of generous welfare entitlements (Maughan 2010).

The Immigration and Asylum Act of 1999 ingrained a dual strategy of restricting entry to the United Kingdom and reducing social citizenship rights for asylum seekers (Bloch 2010). The Bill entered parliament at a time when the Conservatives were critical of Labour, claiming that Tony Blair's government was a "soft touch" for bogus asylum seekers (William Hague 2000, cited in Maughan 2010, 16). It justified firmer controls as being crucial to the promotion of race relations (Maughan 2010) and went on to extend the Carriers Liability Act by including trucking companies and train passenger services.

The Bill provided a new legal framework for the detention of asylum seekers to combat illegal entry and strengthened the hand of the home secretary by expanding powers to search, arrest, and detain asylum seekers (Sales 2002). Under the 1999 Act, asylum seekers who have been waiting for more than five years for their case to be heard may be granted indefinite leave to remain and those who have been waiting for between three and five years will receive four years leave to remain (Bloch and Schuster 2005). A new cashless voucher system for asylum seekers was also introduced but abolished in $2002 .{ }^{16}$ The policy sought to reduce the backlog of cases and introduced the forced dispersal of asylum seekers to relieve the concentration of claimants living and working in London and South-East England. ${ }^{17}$ The dispersal system was also perceived as a form of social engineering where asylum seekers were dispersed to areas of economic decline and elevated levels of crime and violence. In addition, local authority administered welfare was linked to immigration status (Cohen 2002). In 2000, the National Asylum Support Service was created to administer the new system. The Act also increased the powers of immigration officers to arrest and detain people, as well as expanded the use of immigration detention with the capacity for detention quadrupling to 4,000 people at any time.

\section{From 2000, Onward: Further Curbs}

Tony Blair, faced with a surge of asylum cases that coincided with the breakup of the former Yugoslavia and the wars in Afghanistan and Iraq,

\footnotetext{
${ }^{16}$ The vouchers were not only controversial, the system was difficult to implement but the principle that asylum seekers should not be incentivized by benefits was first mooted in 1999 and remained intact until today (Singh 2010).

${ }^{17}$ Britain was not unique in facing large backlogs in the asylum process. Germany had also grappled with the problem in the mid-1990s and in both countries there was a tension between protections under due process and speedy, efficient decision making. Nor was Britain unusual in adopting a dispersal scheme. France had in the 1970s decentralized its provision of hostel space for asylum seekers around the country resulting in a "de facto dispersal" (Kofman 2002, 1043). Italy, in the late 1990s, was unprepared for the considerable number of refugees fleeing the Balkans crisis and adopted a mixed approach in which the state set up dispersed reception centers primarily in small communities and NGOs also became involved in providing shelter (Kofman 2002).
} 
sought to dilute Britain's commitments under international law. Unable to do so under the ECHR without breaching the terms of Britain's membership of the European Union (Watt and Wintour 2015), Blair lobbied unsuccessfully for the operational modernization of the 1951 Refugee Convention to keep pace with a "changed" environment and a "vastly increased" number of asylum seekers (Mulvey 2010, 440). ${ }^{18}$ When that failed, Blair adopted a twopronged strategy. First, he sought to protect refugees from the Balkans conflict through UN safe havens in the region, so they had no need to seek humanitarian refuge in Britain (Sales 2005). The second comprised a raft of British policy enactments after 2000 intended to further curb entry by dramatically increasing surveillance and monitoring at the borders. These "criminalized the process" of seeking asylum by limiting the citizenship rights of refugees (Back et al. 2002).

The Nationality, Immigration, and Asylum Act of 2002 introduced many radical measures including a provision to allow the children of failed asylum seekers to be taken into care, restricting the remit of the Immigration Appeal Tribunal (IAT) to errors of law (Webber 2008), and abolishing the automatic right to a bail hearing. ${ }^{19}$ It repealed the provision of automatic bail hearings created by the Immigration and Asylum Act of 1999, granting wider powers to those who authorize and extend bail to enter premises and detain (The Guardian 2009b). This meant that an asylum seeker can be detained at any time during their application, not just prior to removal. It again created a White List of safe countries. ${ }^{20}$ This meant citizens of these designated countries who have their asylum applications rejected could not remain in the United Kingdom while they mounted an appeal. It also made provision to deport asylum seekers to a safe-third country without appeal with the presumption that countries newly admitted to the European Union would fall within the "safe" category (Keyes 2004). A joint parliamentary committee described this as an "unacceptable" threat to human rights and strongly criticized the enactment of a provision that withdrew refugee protection from people convicted of serious criminal offences as contrary to the U.K.'s obligations under the Refugee Convention, as it allowed deportation even for crimes that were not "particularly serious" (The Guardian 2009b).

\footnotetext{
${ }^{18}$ Blair's call for changes to international treaties on refugees echoed a similar one by Home Secretary Jack Straw and controversial proposals by the Austrian government in 1998 (Gibney 2001).

${ }^{19}$ There were successive attempts by the Labour government to restrict failed asylum seekers to a single right of appeal and attempts to restrict access to higher courts. The measures were legally challenged and had to be abandoned, but as Geoff Mulvey has argued, they remained policy goals and symbols in a rhetoric of illegitimate applicants (2010).

${ }^{20}$ The safe country of origin concept gives the home secretary power to designate a country "safe" in that in general there is "no serious risk of persecution" to those living there and deportation there would "not in general contravene" the European Convention. There is no appeal against designation but it may be challenged by judicial review (Refugee Council n.d.).
} 
One of the most controversial aspects of the Act was the decision to remove support for destitute asylum seekers who would now have to prove that they were destitute and that the application for asylum had been made "as soon as reasonably practicable" upon arrival in the United Kingdom (Keyes 2004, 409). Furthermore, the home secretary could withhold support from applicants who could not provide an account of how they had arrived in the United Kingdom, how they had been living since their arrival, or to anyone who did not cooperate with the authorities. The Refugee Council raised concerns that this would potentially push thousands of asylum applicants in the United Kingdom into extreme poverty making it more difficult to pursue their asylum application, forcing them to choose between persecution or destitution (Sales 2005). In 2004, the Court of Appeal found that the policy of denying support to destitute asylum seekers breached Article 3 of the ECHR and in October 2004 the home secretary abandoned the policy (Callaghan 2004).

In view of the criticism of the 2002 Act, new legislation was mooted, which the Home Office claimed would introduce "speed and finality to the appeals and removals process and ensure traffickers and asylum claimants do not benefit from dishonesty or by attempting to mislead the authorities" (The Guardian 2009b). The primary aim of the Asylum and Immigration (Treatment of Claimants) Act of 2004 was to limit the role of courts in immigration appeals replacing the earlier system of immigration adjudicators and the IAT with a singletier asylum and immigration tribunal. Controversially, it also removed judicial review, cutting off all appeals to the Court of Appeal and the House of Lords except in cases that involve an error of law. The government justified this single tier of appeal as seeking to deter legal advisers from abusing the system while failing the claimant and enabling the government to deport failed asylum seekers "without further judicial interference" (Blair 2003).

Second, the single-tier system was also justified on the basis that the appeals succeed in only a small percentage of cases, and the changes would prevent asylum seekers from trying to "play the system" in order to remain in the United Kingdom (House of Commons 2003). This was in tandem with the government's crackdown on asylum seekers who deliberately destroy or discard their travel documents (Mulvey 2010). It created criminal sanctions to punish people who arrive in the United Kingdom without a valid travel document unless they have a reasonable excuse not to have one or will not cooperate with the authorities to get new travel documents when their claims fail. The government claimed that more than 60 percent of asylum seekers had no documents and that this was the single biggest barrier to dealing with their applications and returning them to their country of origin if their claim failed (House of Commons 2003). The Refugee Council noted the Act was "a worrying trend within the United Kingdom's asylum procedures of judging an asylum application by looking at how an individual came to claim asylum rather than why they had to flee" (The Guardian 2009b).

The Act also empowered the authorities to refuse welfare support to failed asylum seekers with dependents, the children would be supported but could be 
removed from their parents (Mulvey 2010). Enforcement authorities were also allowed to tag, track, and use voice recognition technology to trace asylum seekers (House of Commons 2003). It also made the provision of accommodation to failed asylum seekers who cannot return home immediately conditional upon the participation in community activities. It replaced back payments of income support and related benefits to refugees with a loans system. It also targeted "sham marriages" requiring foreign nationals from outside the European Economic Area to get written permission from the Home Office before getting married in Britain (Bosworth and Guild 2008). In 2007, the government lost its appeal against an earlier court ruling that its "sham marriages" provisions were unlawful, as no certificate was required for those who wished to marry in the Church of England (Summers 2007). Like the 2002 Act, the 2004 Act raised serious concerns about the decision to refuse support to asylum seekers with minor dependants and was seen as breaching Article 8 of the ECHR because it forces "parents to choose between keeping children with them on the streets or asking a local authority to provide the children with accommodation on their own" (The Guardian 2009a).

Following the 2004 Act, the Immigration, Asylum, and Nationality Act of 2006 sought to implement the key legislative aspects of the Home Office's fiveyear strategy for asylum and immigration. It sought to further reform the immigration and asylum system, building on and amending the measures introduced in the Immigration Acts of 1999, 2002, and 2004 (The Guardian 2009a). It further restricted appeal for those refused entry to the United Kingdom to work or study. Only asylum refusals made in Britain carry a full right of appeal. It further empowered immigration officers to confiscate travel documents and record and verify biometric information from people entering the United Kingdom. It enlarged powers for the police to obtain advanced information on passengers and crew or freight ships and aircraft arriving, expected to arrive, leaving, or expected to leave the United Kingdom. The Act required that asylum is refused to anyone who has carried out or has encouraged others to "commit, prepare or instigate terrorism" (The Guardian 2009a). It expanded powers for the home secretary to certify that a person shall be excluded from protection under the convention relating to the status of refugees if they are deemed to be a terrorist or major criminal. The Borders, Citizenship, and Immigration Act of 2009 retained the government's policy on the detention of child asylum seekers but also required the U.K. Border Agency and private contractors to promote the welfare of children in line with Section 11 of the Children's Act 2004 (Kelly and Bokhari 2012).

\section{From 2010: Era of "Open Hostility"}

Policy enactments under the Cameron and May governments further intensified and accelerated patterns laid down by their predecessors. The 1996 Act had removed asylum seekers from the mainstream benefit system and created a 
parallel system of support run by a division of the Home Office. In the era of austerity the most vulnerable were subjected to further budget cuts and many of those eking out a highly marginal existence were left destitute and homeless, and children were particularly hard hit by the cuts (Refugee Action 2017). The 2014 and 2016 Immigration Acts were intended to "create a hostile environment" (Travis 2013) by expanding border controls in Britain in everyday life activities by requiring banks, driving licenses, hospitals, and landlords to do basic immigration checks. The intention was to restrict access to work, shelter, health care, and education (Yuval-Davis, Wemyss, and Cassidy 2017). At the same time, the United Kingdom ring-fenced the development aid budget used in part to support the humanitarian work of the UN in refugee camps in Africa and the Middle East (Ibrahim and Howarth 2017). Principles first introduced in 1987 and strengthened in 1999 which held carriers legally accountable for the inadvertent transportation of illegal migrants were extended to other economic activities making the employment of, or renting to, an illegal migrant a criminal offence. The government's "deport first, appeal later" scheme was extended to all migrants unless it would cause them "serious irreversible harm" (Partos and Bale 2015). In addition, visa restrictions were tightened in specifying how much U.K. nationals had to earn before they could bring over a non-European Union spouse, children, or elderly parents in need of care (Travis 2017).

The 2016 Act restricted the detention of pregnant women to 72 hours and included the so-called "Dubs Amendment" on unaccompanied refugee children in the European Union. The amendment, which initially had widespread public and media backing (McLaughlin 2017), required the government to accept unaccompanied children already in the European Union (including in Calais) but provided for discretion as to how many children were admitted and a cut-off point for eligibility. Britain was already required under the Dublin Regulations to allow minors already in the European Union and with close family ties in Britain to enter before applying for asylum. The United Kingdom, however, dragged its feet in accepting unaccompanied children, particularly in Calais (Ibrahim and Howarth 2018). The government also consistently refused to accept unaccompanied children with no family ties unless they were Syrian refugees in the UN camps in North Africa (Wintour 2015). Rather than face parliamentary defeat, the government allowed the amendment to go through unopposed (Asthana, Mason, and McVeigh 2016). Nevertheless, the implementation of the Dubs Amendment and the Dublin Regulations on children was heavily criticized as wholly inadequate when the informal camps in Calais were demolished and Britain exhibited reticence in accepting these displaced children (Rogers 2017).

\section{Analysis: A Hollowing out of Humanitarian Refuge while Retaining the Myth}

Our historic overview of legislative activity traced the emergence of a "distinctive" British tradition of humanitarian refuge from the nineteenth 
century, a period of open borders that coincided with a new secular morality centered on the human in relation to the state to the unapologetically hostile environment of the 2016 Immigration Act. Three themes emerge from the overview. First, the emergence of a romanticized ideal of a British "tradition" and its subsequent effacement with racialized distinctions between the deserving and undeserving. Second, the cumulative erosion of welfare support reducingparticularly the unsuccessful-asylum seeker to destitution and deportation. And third, the proliferation of legislative activity from 2000 that created a sense of a system in perpetual "crisis" (Mulvey 2010). These justified more draconian measures in an escalating spiral of hostility toward migration and the seeking of asylum, coalescing the approaches between the two categories.

The absence of border controls until the 1905 Aliens Act was necessary but insufficient for the emergence of refuge as a humanitarian category and "moral norm" (Shaw 2015, 6, 7) or for a sense of a British distinctiveness because much of Europe only began reinstating border controls during the course of the nineteenth century (Bashford and McAdam 2014). The differentiation in a political and public imagining arose out of a comparative lack of restrictive new laws or discrimination based on politics or religion and the refusal to concede to demands by other European states to extradite revolutionaries. The perception of Britain as a unique space of sanctuary unmediated by political or religious discrimination was shared across Europe from the 1850s (Rabben 2011; Shaw 2015). In Victorian Britain, it chimed with a sense of the nation's evolution into the most morally superior and enlightened in Europe.

The notion of the vulnerable human in need of protection has ancient roots, the difference being that by the Victorian era the "human" had become the central moral figure in refuge while in ancient and medieval sanctuary God/the gods were. The protection offered to those in need was by the morally upright rather than out of fear of God/the gods and the discretion to grant refuge was until relatively recently exercised by ministers rather than bishops. The humanitarian sentiment did not displace ancient and medieval understandings of sanctuary so much as reconstitute them into modern secular notions of humanitarian refuge. Parliament had formally abolished church sanctuary in 1624 but the practices continued informally into the eighteenth century. The evolution of sanctuary practices into a more secular form in the nineteenth century melded the religious notion of sacred space with Kantian meanings of humanitarianism. The latter emerged from a moral imperative to alleviate human suffering, delineating the distinctive role of the nation state in offering humanitarian refuge within its borders to those fleeing war, conflict, and persecution. In Victorian Britain, the idea of a distinctive tradition of humanitarian refuge was a powerful social force in that the public and media imagining of the tradition took it for granted that those seeking refuge would not be turned away (Rabben 2011). Despite the lofty ideals and self-image of superior moral standing in Victorian Britain, in reality while exiles were free to stay, many starved in conditions of destitution and the government sent the unwanted, at times secretly funding their passage, to the colonies (Rabben 2011, 61). 
The historic trajectory of humanitarian refuge as a Victorian ideal was nevertheless disrupted by global developments, briefly resurrected with the international treaties on refugees, and then eroded in Britain by the stigmatizing of refugees. The first development was the emergence of mass forced displacement beginning with the flight of the Ashkenazi Jews in the 1880s, reaching unprecedented levels in the twentieth and twenty-first centuries in two world wars, the breakup of empires and federations in Europe, and culminating in the contemporary refugee crisis. The second was the loss of an empire, which had two implications for the British tradition. The government could no longer send unwanted refugees to the colonies as a mechanism of exclusion while still holding to the ideal of humanitarian refuge. Ministers also feared a large influx of the formerly colonized fleeing postliberation war, persecution, and torture, and from the 1960s the government steadily legislated to restrict the entry of commonwealth citizens. The cumulative legislative responses to these developments progressively effaced the practices of humanitarian refuge and tightened border controls, truncating the latter as part of increased state securitization particularly after 9/11. These culminated into open conflict and brutalizing policies toward the figure of the refugee.

The refugee protections inserted into the Aliens Act of 1905 did not survive the outbreak of World War I or the influx of Jewish refugees from Nazism, a development that retriggered the xenophobic arguments that circulated during the 1904 debate on the Aliens Bill (London 2003). Nevertheless, a variant of these was reinstalled in legislation after World War II. What remained from the 1905 Act and shaped the policy imperative and legislative activity for the next 120 years was intense racialization of immigration policies with the withdrawal of Britain from its colonies and the coalescing of immigration control with asylum policies resulting in an overt stigmatization of the refugee as an opportunist who would deplete the coffers of the United Kingdom and its welfare system. The erosion of the state's responsibility toward the displaced and persecuted meant that Britain's notion of humanitarianism was increasingly envisaged through a reduced commitment to the provision of refuge and the management of forced displacement through an externalization approach which relegated border control to other countries (Ibrahim and Howarth 2017).

While anti-Semitism shaped the distinction between the wanted and unwanted, it did not appear on the face of the 1905 Act, but such inhibitions evaporated from the 1960s in an escalating politics of race. There were wider social tensions around immigration from the former colonies and fears that the displaced from the newly liberated colonies or the opportunistic attracted by the new welfare state would "flood" into Britain. Right-wing political rhetoric tapped into atavistic fears of being overwhelmed numerically and by racial, cultural and ideological differences "portending the demise" of a valued way of life (Bauman 2016, 1). The tensions ignited into several race riots between the late 1950 s and early 1980s. Rationales for some legislative activity from the 1960s were clearly racially motivated (Dembour 2015) but one of the key 
rationales for legislating on asylum provided by the 1997 Blair government was a concern with managing race relations, an issue of public order (Maughan 2010).

A key instrument in the hollowing out of humanitarian refuge was the revival of distinctions between the deserving and the undeserving where these often intersected with race, religion, and ethnicity. In Medieval and Reformation Europe, the distinctions were religious or criminal rather than racial, in Revolutionary Europe, they were political, while in Britain after 1905, they became racialized - at times overlapping with fear of the Jews and Muslimsand increasingly pejorative. The specification of the "undesirable" as criminals, diseased, and destitute which plastered a fig leaf over the racism in the 1905 Aliens Act morphed in the 1971 and 1981 Acts into new overt racial categorizing of "patrials" and "nonpatrials." From the 1990s, racism shifted from a categorization of racial difference based on parentage into a rhetoric of "genuine" versus "bogus" asylum seeker which reconfigured asylum seekers not as heroic figures or objects of pity but as the fraudulent and criminal posing a risk to the society that hosted them. The rhetoric and the illogic underpinning it were rebuked by UN Secretary General Kofi Annan in 2014, saying: "[l]et us remember that a bogus asylum-seeker it not equivalent to a criminal; and that an unsuccessful asylum application is not equivalent to a bogus one" (UNHCR 2014).

Domestically, the dichotomizing of the deserving and undeserving served two purposes beyond fragmenting asylum seekers as a category and stigmatizing most. The "deserving" granted refugee status allowed for a continuation of the romantic ideal of humanitarian refuge and a sense of compliance with international agreements. The criminalizing of the "undeserving" made it possible to reconstitute them, not as objects of pity as they had been in Victorian era of humanitarian refuge, but suspect figures either smuggled into Britain through complicity with criminal networks, or as opportunistic parasites on the welfare system, or as economic migrants fraudulently claiming to have been persecuted. The shifting of terms between the "migrant" and the "refugee" meant these became blurred categories reducing a moral caution in approaching the displaced or those at risk.

From the 1980s, the domestic agenda on asylum began to incorporate some of the more coercive of European Union directives unmediated by the protective elements. Brutalizing and dehumanizing technologies were deployed such as dispersal around the country and containment in detention centers, deportation to where they first entered the European Union, to their country of origin, or a third country. None of these were unique to Britain but the intensity with which they were implemented was manifest in the material consequences of a dramatic expansion in Britain's detention estate into one of the largest in Europe (Silverman and Hajela 2015). Another consequence of taking asylum seekers out of the mainstream welfare system in 1996 was that it made the Home Office responsible for their financial support. Welfare support became a 
punitive technology of dehumanizing and degradation in systematic strategy intended to cut the number of asylum applications and increase deportations. The worst affected were those whose claims had been refused and were subjected to what NGOs called "forced, state-sanctioned absolute poverty" (O'Neill 2017) and many of the mainly invisible were driven into destitution, prostitution, and modern slavery (Webber 2008). NGOs labeled it a "starve them out" strategy based on the false premise that people would return to war zones, persecution, and torture if they are denied food and shelter in the United Kingdom (Blanchard and Joy 2017).

The distinctive British tradition of humanitarian refuge had become a shell. The three central tenets of the romantic ideal-lack of restrictive laws, nondiscrimination, and the refusal to extradite or deport-had all but disappeared within just over a century. Zygmunt Bauman (2016) has suggested that stigmatizing the stranger who comes in search of sanctuary is a rhetorical device to negotiate dissonance between the ideals of humanitarian refuge and the increasing harshness of the response. Reconfiguring the refugee as a suspect figure enables a reconfiguring of space, from one of hospitality to hostility. Mulvey (2010) argues that in presenting asylum seekers as unwanted and constantly subsumed through legislative activity, the Blair government conveyed an asylum system in perpetual crisis. The visceral politics followed the policies as the government lost control of the debate and the hostility it helped foster in the media and public sphere. The outcome was a "vicious cycle of hostility" (Mulvey 2010, 456) which our analysis of the Conservative government of 2010 suggests is still spiraling and made manifest through fragmented and short-term solutions to the humanitarian crisis in Europe. While the Ancient Greeks had feared the vengeance of the gods if sanctuary was refused, British political leaders from Blair to May have feared the revenge of voters at elections over "uncontrolled" immigration. Where Victorian governments had feared the government would fall if sanctuary was refused, the contemporary fear is that the government could fall if migration and asylum seeker numbers are not tightly controlled and regulated (Maughan 2010).

\section{The European Union and Externalization of Border Controls}

While the six phases discussed earlier outline the approach toward immigration and asylum in the United Kingdom, Britain's entanglement with the European community and the European Union produced renewed tensions concerning immigration through the expansion of the European Union and the admission, in particular, of Eastern European member states such as Poland, Romania, and Bulgaria. Anxieties over the inclusion of new Eastern European states were reflected in newspaper discourses and often became part of election debate. More significantly, they circulated the resonant discourses concerning the United Kingdom being attractive to these new states due to its welfare system (Ibrahim and Howarth 2016). 
Britain joined the European Community in 1973 amidst a perceived risk that the demise of the empire would lead to a loss of markets and marginalization in a globalizing world. Despite this union, closer ties to Europe produced sustained anxieties concerning the European Union being a threat to British sovereignty and identity based on Britain's spatial separation as an island and equally its historical and racial distinctiveness (Daddow 2013; Wall 2012). With the Maastricht Treaty of 1991 the Community was turned into a Union (i.e., from a predominantly trading block to a more political entity with looser internal borders). France and the United Kingdom reached an agreement to place juxtaposed controls (i.e., immigration checks) at designated cross-Channel sites, including at Coquelles near Calais. These controls meant checks took place before boarding a train or ferry rather than on arrival. In 1995, the Schengen Agreement was signed allowing for the removal of internal borders between signatory states with the purpose of further facilitating the efficient movement of people. Britain, choosing neither to cede its sovereignty or identity, opted out of the Schengen Agreement.

The borders of the European Union have been fluid, with six waves of enlargement. In 1973, it moved westward with the inclusion of the United Kingdom and Ireland, in the 1980s it pushed southward to the Mediterranean to Greece, in the 1990s, northward to encompass some of Scandinavia, and eastward after the new millennium to include Hungary and Croatia, bringing the total number of member states to 28 . Membership also brought access to new markets and led to mobility of labor. Migration issues had become highly politicized in most western European states from the 1980s onward, and political parties were competing for electoral support with promises to restrict "unwanted" migration. Two major migration narratives have dominated British public debate since the 1990s: loss of control over borders and the economic threat of migration through expansion of European Union membership. The expansion of the European Union to include Poland in 2004 and Bulgaria and Romania in 2007 produced much anxiety concerning migrants from these countries threatening job security, welfare services, national identity, and sovereignty (Darian-Smith 1999; Sellar et al. 2009).

The breakup of the Soviet Union, the Eastern Bloc, and the former Yugoslavia in the 1990s shifted the dominant discourse away from rights, protection, and refuge to threats posed by "unregulated, unaccountable population shifts" to the political stability and cohesion of the states (Bosworth 2008). From the late 1990s, there has also been growing concern about people trafficking and smuggling and, after $9 / 11$, about the possibility of terrorists infiltrating the asylum seeker-migrant routes. Intense cooperation with the European Union meant shared offshore immigration controls and pre-inspection, participation in European Union measures to police the Mediterranean through Frontexthe European Union agency tasked with coordinating border security-operations, schemes for offshore processing, and fines on carriers that bring individuals without documents to the United Kingdom. 
From the late 1980s and into the 1990s, the externalization of border control, restrictive asylum systems, and cooperation to combat migrant smuggling and trafficking were effective instruments for curtailing migration. The loss of national control over borders created the perceived need for "flanking" measures between European Union countries and a range of extraterritorial migration control measures with countries of origin and transit countries in recent years. The external dimension of European Union immigration and asylum policy was nevertheless only formally embraced by the European Council in October 1999. This externalization approach has meant cooperation with migrant-sending countries and the "transit" countries through which migrants and refugees travel.

This externalization approach entails more intensive cooperation with countries of origin and/or transit countries and involves the exportation of traditional migration control instruments to transit countries outside the European Union. These instruments encompass border control, measures to combat illegal migration, smuggling and trafficking, and capacity building of asylum systems and migration management in transit countries. The second element of externalization comprises a series of provisions for facilitating the return of asylum seekers and illegal migrants to third countries. These involve readmission agreements with third countries, committing them to readmit irregular immigrants who had passed through their territory into European Union countries, or were their nationals. Other provisions on safe third countries allowed European Union states to return asylum seekers to countries from which they came or through which they had passed which were considered "safe." These third countries were obliged to apply European Union standards of migration management, or to enter agreements for readmitting irregular migrants. Justice and home affairs officials were keen to transfer national control mechanisms not just to the European Union level, but further afield. Nevertheless, these measures raise serious concerns about the legality and ethics of denying refugees the right to seek asylum, and equally the acceptability of passing on the U.K.'s asylum "burden" to other-often poorer - states closer to regions of refugee origin (Gibney 2004; McAdam 2008).

\section{The Contemporary Refugee Crisis}

The effacing of humanitarian refuge at home was accompanied by contracting humanitarianism abroad in a way that enabled the government to maintain the semblance of a British tradition. Cameron and May accelerated and hardened hierarchies of legitimacy which distinguished between those deserving and undeserving of pity, those for whom state-funded humanitarian assistance was targeted and those for whom it was denied unless provided by the voluntary sector. May's time at the Home Office had marked further restrictions and marginalization of asylum seekers in measures that critics viewed as "nasty," "vindictive" (Sheikh 2016), and racialized, intended to deter those seeking humanitarian refuge from coming to the United Kingdom in the first place. 
Unsurprisingly, the responses to the unfolding humanitarian crisis in North Africa, the Mediterranean, and Calais seek to keep refugees at a distance and control who could enter Britain. May's "vision" was most clearly outlined in one of her first major speeches as prime minister. She proposed a "new global approach to migration" based on three fundamental principles: ensuring refugees claim asylum in the first safe country they reach, improving how to distinguish between refugees and economic migrants, and a "better overall approach" to managing economic migration based on the premise that "all countries have the right to control their borders... [and to] commit to accepting the return of their own nationals when they have no right to remain elsewhere" (May 2016).

Given the growing hostility toward asylum in the United Kingdom, David Cameron and Theresa May were lukewarm in their responses to the mounting crises in the Mediterranean and Calais. Critics argue that their resistance to take in refugees constituted an "abandonment of the United Kingdom's "humanitarian traditions"” (Borger 2015). Stung by the criticism, Cameron and May reiterated the British government's humanitarian imperative that privileged Syrian refugees who had fled to neighboring countries and UN camps as opposed to those who had undertaken the treacherous journey to cross the Mediterranean. While the Syrians remained in their immediate neighboring regions, the British government considered them refugees deserving of pity. By January 2016, the United Kingdom had committed $£ 1.12$ billion to support the humanitarian work of the UN and the governments of Lebanon and Jordan, including $£ 23$ million for the UN to distribute aid on the ground to "help the most vulnerable in the hardest-to-reach parts of Syria" (May 2016). The United Kingdom operated on the assumption that if the needs and aspirations of refugees were met in the region, the refugees were less likely to migrate to Europe (May 2015b). They also vetted the "most vulnerable" in the UN camps and granted them safe passage and "sanctuary" in Britain (Cameron 2015). The refuge element of the U.K. humanitarian response remains highly regulated and guarded, retaining it through a protocol of tight controls and externalization of border controls and processing of applications.

The foreign policy responses also reiterated the racialization and criminalization of asylum seekers that characterized 120 years of domestic policy making. Cameron and May privileged the taking of Syrian refugees from the UN camps but made no mention of doing likewise for Eritreans, Somalians, Iraqis, or Afghans (Ibrahim and Howarth 2017). Those that left the region and risked their lives crossing the Mediterranean were relabeled "migrants" and seen as both victims preyed upon by the criminal smuggling networks taking them across the sea and complicit in risking their lives and those of their children to get to Europe (Craig 2015). Deemed less deserving of pity once they left the region, the U.K.'s policy imperative for the Mediterranean emphasized disrupting people smuggling on the European Union's southern borders, with the Royal Navy's ships deployed primarily for that purpose rather than attending to the trauma of forced migration (Ibrahim and Howarth 2017). The 
government, in a tone of rectitude, held tightly to the precept in the Dublin Regulation that those "migrants" that landed in the European Union were expected to apply for asylum in the first country they set foot in. While exercising their opt-out from European asylum directives in refusing to take refugees from within the European Union, the United Kingdom made a gesture of support for its counterparts in Greece, Spain, and Italy by sending technical experts and translators to reception "hotspots" to assist with the processing of claims in the hope that most would apply there. However, those displaced who delayed with a view to applying for asylum in Britain and traveled to Calais to attempt to do so, were deemed by the government to be "illegal migrants," and British "investment" was targeted at augmenting security measures and border patrols (May 2015a) intended to obstruct them from achieving their objective of reaching Britain. This label of illegal migrant narrated these displaced bodies through an illegitimacy not deserving of either sympathy or taxpayer's money.

This crude categorizing of the displaced through forced migration illustrated May's bifurcation of the humanitarian imperative, directing it "upstream" with the intention of keeping refugees in the region (May 2015a) while "downstream" in Calais the securitization imperative sought to actively discourage new "illegal migrants" to the area and obstruct entry to Britain. The spatial categorizations also served to justify the distinction between the deserving and the undeserving, but it also cast into sharp relief the nature of contracted humanitarianism and the U.K.'s nonproximate approach of keeping refugees away from its borders.

The Dubs Amendment, while framed widely to include unaccompanied or lone children anywhere in the European Union, was primarily targeted at those in Calais. British public opinion has been hardening against migration and asylum seekers for decades and the government felt able after the 2009 demolition of the "jungle" (i.e., makeshift refugee camps) in Calais to refuse admitting children despite pressure from NGOs to do so. In 2016, reports began to emerge from the UN that 25,846 unaccompanied children, orphans, and those separated from their family, had entered the European Union and were vulnerable to exploitation and trafficking (UNHCR 2017). Nevertheless, mounting public pressure, political opposition, and media discourses of children living in ditches or flimsy tents or simply disappearing with the demolition of the jungle raised alarm in the public domain. As representatives from across the political spectrum, media, and public opinion lobbied for an exception to be made for child refugees, Cameron agreed that the government would not oppose the Dubs Amendment but would retain discretion on the numbers allowed in, based on what local councils said they could afford, and placed a restriction on when the child entered the European Union. Notwithstanding legislative provisions for two categories of children (i.e., those with close families and those unaccompanied) to apply for asylum in Britain, there were lengthy delays in implementing the measures. 
With the present refugee crisis in Europe, humanitarian work was outsourced in Calais to voluntary organizations, and in North Africa to the UN. While refusing to accept refugees from within the European Union generally or Calais specifically in 2014, the government under mounting public pressure relented to accept 20,000 "vulnerable" Syrian "refugees" from UN camps in Lebanon, Jordan, and Turkey (Brokenshire 2014). In 2015, within weeks after the image of Alan Kurdi went viral, the Ministerial Committee for Syrian Refugees was set up and a special post of Minister for Syrian Refugees was created in the Home Office (Cameron and May 2015). Only a chosen few, vetted by the UN and the Home Office before they got to Europe, were offered refuge based on those the government deemed to be "most in need," including children and those most likely to be granted refugee status in Britain. This "upstream" response to the humanitarian crisis of offering refuge sanctuary to those vetted outside the European Union was an integral part of the U.K.'s nonproximate approach in delimiting the humanitarian imperative to outside the borders of the European Union.

\section{From the Aliens Act to the Present Refugee Crisis}

Our review of policies from the mid-1800s to the Aliens Act of 1905 shows that the fatigued contemporary figures of the refugee and asylum seeker are historical conceptions born from a romantic and moral ideal of sanctuary and refuge which over time descend into a shattered myth. The road from civilized hospitality to hostility is a story of curtailment where the "recourse to funds" caveat introduced with the Aliens Act produces a carte blanche in policy terms to constantly review the terms of sanctuary and refuge. What it gives way to is a politics of attrition where the terms of reference in enabling refugee or asylum seeker status are scrutinized through the lens of these entities depleting the coffers, and in the process, they become suspect bodies apparently bent on exploiting the welfare system in the United Kingdom. The interchangeable terminologies between migrant and refugee in political discourses locate them through opportunism rather than highlighting the risks and trauma they should be protected from. The policy review from the Aliens Act points to an intense process of curtailment in terms of numbers and disciplining the vulnerable through policy paradigms, particularly in severing historical ties to the colonies and introducing new legislation to requalify the right to citizenship through descent.

The promulgation of the Aliens Act in 1905 retained the notion of refuge but the passage of the Bill witnessed extreme racialized discourses concerning who should be admitted and who should not. This racialization of migration both in political discourse and in practice would ensue for years to come from the demise of the empire, the expansion of the European Union, the fallout from Brexit, to the present-day humanitarian crisis. Most significantly, the Aliens Act enshrined in law the category of the refugee, and conjoined immigration with welfare, specifically the notion of "recourse to public funds." The 
retention of the Enlightenment ideals and mythic elements of refuge within the policy paradigm and the conjoining of welfare with the immigrant would lead to more than 100 years of policy making which would not only be severely racialized with the crumbling of empire, but one which would slide into the harsh politics of curtailment - of bodies, liberties, and funding. The historical discourses of hospitality and magnanimity symbolizing a civilized and enlightened polity would over time be confronted with xenophobic anxieties and also a domestic politics of depletion of welfare through the movement of refugees and asylum seekers into the United Kingdom. The provision of refuge becomes a politics of controlling, disciplining, and curbing the refugee body through policy enactments while retaining the refuge for the persecuted as a romantic ideal. The notion of human rights, particularly with regard to the refugee and asylum seeker, became a malleable category. Despite being a signatory to the 1951 Geneva Convention and the ECHR (1953), these would only be integrated into British domestic law in 2000.

The tight control of immigration, particularly from the Commonwealth from the 1960s, and the racialization of immigration through exclusion based on the notion of patriality and the replacement of citizenship through descent rather than place of birth were a manifest racialization of immigration policies, both as a measure and symbol of whom they admitted and bestowed citizenship rights to. The Queen as the protector of the empire gave way to policies which sought to reduce the U.K.'s obligations to its former colonies. In the 1990s, the ambit of policy making focused on asylum and would remain an area of tension and criticism in terms of party politics for subsequent Labour and Conservative governments and as an emotive election issue, with refugees portrayed as exploiting not just welfare benefits but core British values. Successive governments would lobby for the change of the asylum system arguing that it was not fit for purpose given the increasing number of claimants. The asylum seeker's recourse to public funds is an arena of visceral politics, often igniting criticisms concerning the U.K.'s "soft touch" and casting renewed doubts over the "bogus asylum seeker" and the United Kingdom being a magnet for these suspect figures due to its generous welfare provisions. The enactments to regulate the asylum seeker, from the 1993 Immigration Act to the Dubs Amendment in 2016, would seek to increase the powers of authorities while tightly controlling the asylum seekers' citizenship rights and civil liberties with respect to employment, accommodation, subsistence, right of appeal, detention, and deportation. Since 9/11 increased securitization and terrorism have converged with the suspect figure of the "refugee and asylum seeker" not just posting threats to the benefit system but cultural and security risks too.

The U.K.'s membership of the European Community and the European Union produced new forms of tension in terms of European migration into the United Kingdom and the need to comply with the ECHR. The United Kingdom opted out of the Schengen Agreement that entailed the systematic abolition of the internal border controls and a common visa policy, choosing instead 
to retain control over its own borders. The addition of new member states in Eastern Europe would similarly produce paranoia in the media and public discourse concerning migration and the claiming of welfare benefits. Membership of the European Union would see intense cooperation in offshore immigration controls and the externalization of border control through Frontex. The externalization of border control through "flanking" measures through a range of extraterritorial migration control initiatives with countries of origin and transit countries in recent years has enabled the United Kingdom to distance itself from the humanitarian crises. In effect it has put the onus on migrant-sending countries and the "transit" countries through which migrants and refugees travel to process and control forced migration from conflict zones. This nonproximate approach of externalization and outsourcing to third parties raises grave concerns about the legality and ethics of managing the figure of the refugee and asylum seeker and passing on the burden to other often less economically powerful countries.

Equally the outsourcing of humanitarian work to NGOs in Calais, and measures to retain Syrian refugees in the region and to process them through UN camps equally reiterates the nonproximate approach where refugees closer to the border are treated as migrants rather than refugees. The shifting of the U.K.'s imperative in the Mediterranean from "search and rescue" to disrupting human smuggling highlights the U.K.'s contracting humanitarianism. Their approach of open hostility, particularly under May's regime, marks the demise of humanitarianism where aid is meant to retain refugees in the region rather than crossing over to Europe. The crossover into the borders of Europe and the United Kingdom delegitimizes them as opportunistic migrants rather than refugees in need of protection and hospitality.

\section{Conclusion}

We have argued that the emergence of a distinctive British tradition of humanitarian refuge enabled the nation to imagine itself as morally superior to its European counterparts. The tradition was a mix of practices and ideals, more romanticized than reality, that have been severely tested by the challenges of mass forced migration in the twentieth century and the loss of empire. The legislative responses to these challenges have contested these ideals in practice. The contracting of humanitarian refuge and the focus on financial aid and support for the work in UN camps provided a means to retain Britain's compassionate façade in the global stage despite not admitting its quota of refugees in the recent crisis. The vetting of potential asylum seekers in the camps by the UN and Home Office officials meant that these camps could legitimize harsher measures against those who had encroached their borders in Europe and to retain a policy of managing refugees through nonproximate initiatives.

The refugee as a suspect figure mired completely in the domestic politics of depletion emerges through waves of policy enactments where both Labour and 
Conservative governments outdo each other to reform an asylum system which is deemed not fit for its purpose in view of burgeoning numbers. The nation is seen as being besieged through its "soft touch." With the closing of borders to international migration from the colonies in the 1960s, the ambit of policy focuses intensely on the refugee and the asylum seeker as burdens on the state echoing similar reservations with the implementation of the Aliens Act. From the 1990s, the immigration policy imperative shifted from comprehensive policy making to curtailment, controlling the numbers, and curbing civil and human rights of refugees and asylum seekers. Positioned through the domestic politics of depletion they are perceived not as vulnerable people at risk, but suspect and opportunistic figures who pose a threat to the culture and economic security of the nation state. The provision of aid away from British shores and the increased externalization of border controls coupled with the shifting discourses which transform refugees into migrants as they reach the borders of Europe and the United Kingdom, means the romance and ideal of the sanctuary becomes a hollowed-out rhetoric, yet one which is constantly evoked to retain the glory of the empire and its attendant imagination of itself as a civilized entity. The refugee and asylum seeker are boundary objects productive for invoking in the collective British imagination the idea of the United Kingdom as uniquely humanitarian. In reality they are inscribed through the violent and visceral politics of immigration and its politics of depletion.

\section{About the Authors}

Yasmin Ibrahim is a reader in international business and communications at Queen Mary, University of London. Her ongoing research on new media technologies explores the cultural dimensions and social implications of the diffusion of ICTs in different contexts. She also writes extensively on the notions of "Othering" through dominant themes of migration, border controls, Islam, and terrorism.

Anita Howarth is a senior lecturer at Brunel University, London, and researches on risk, politics, and communication particularly on issues of social justice and inclusion. She has published on food poverty, hunger strikes, refugees, and environmental risks. Anita has recently published work on hunger strikes in Guantanamo, food banks in the United Kingdom, and her book on the border politics of Calais, co-authored with Yasmin, due to be published in March 2018.

\section{References}

Asthana, Anushka, Rowena Mason, And Karen MCVeigh. 2016. "David Cameron Announces Concessions on Child Refugees." The Guardian. May 4. Accessed on February 16, 2018. Available online at https://www.theguardian.com/ world/2016/may/04/david-cameron-concessions-syrian-child-refugees 
Back, Les, Michael Keith, Azra Khan, Kalbir Shukra, and John Solomos. 2002. "New Labour's White Heart: Politics, Multiculturalism and the Return of Assimilation." Political Quarterly 73 (4): 445-454. Accessed on February 16, 2018. Available online at http://onlinelibrary.wiley.com/doi/10. 1111/1467-923X.00499/abstract

Barnett, Michael N. 2011. Empire of Humanity. New York, NY: Cornell University Press

Barnett, Michael N., And Thomas G. Weiss. 2011. Humanitarianism Contested: Where Angels Fear to Tread. London: Routledge.

BASHFord, Alison, And JANe MCAdAm. 2014. "The Right to Asylum: Britain's 1905 Aliens Act and the Evolution of Refugee Law." Law and History Review 32 (2): 309-350. Accessed on February 16, 2018. Available online at https://www.academia.edu/6936598/The_Right_to_Asylum_Britains_1905_ Aliens_Act_and_the_Evolution_of_Refugee_Law?auto=download

Bauman, Zygmunt. 2016. Strangers at Our Door. Cambridge, UK: Polity Press.

Blair, TONy. 2003. "Full Text: Blair's Conference Speech (Part 2)." The Guardian. September 30. Accessed on February 16, 2018. Available online at https://www.theguardian.com/politics/2003/sep/30/labourconference.labour5

Blanchard, Catherine, and Sarah Joy. 2017. “Can't Stay. Can't Go. Refused Aylum Seekers Who Cannot be Returned." British Red Cross. Accessed on February 16, 2018. Available online at https://www.asylumaid. org.uk/cant-stay-cant-go-refused-asylum-seekers-cannot-returned/

Bloch, Alice. 2000. "A New Era or More of the Same? Asylum Policy in the UK.” Journal of Refugee Studies 13 (1): 29-42. Accessed on February 16, 2018. Available online at https://academic.oup.com/jrs/article-abstract/13/1/29/ 1673390?redirectedFrom $=$ PDF

- 2010. "Transnational Lives: The Experiences of Zimbabweans in Britain. In Zimbabwe's Exodus: Crisis, Migration and Survival, edited by Jonathan Crush and Daniel Tevera. Kingston, ON: Southern African Migration Programme. 158-178.

Bloch, Alice, AND Liza Schuster. 2005. "At the Extremes of Exclusion: Deportation, Detention and Dispersal." Ethnic and Racial Studies 28 (3): 491-512. Accessed on February 16, 2018. Available online at http://www. tandfonline.com/doi/abs/10.1080/0141987042000337858

Bolton, SAlly. 2003. "Profile: The Seven New Countries on the 'White List." The Guardian. February 14. Accessed on February 16, 2018. Available online at https://www.theguardian.com/uk/2003/feb/14/immigration. immigrationandpublicservices 
BORgER, JULIAN. 2015. "David Miliband: Failure to Take in Refugees an Abandonment of UK's Humanitarian Traditions." The Guardian. September 2. Accessed on February 16, 2018. Available online at https://www.theguardian. com/world/2015/sep/02/david-miliband-refugees-uk-humanitarian-traditions

Bosworth, MARY. 2008. "Border Control and the Limits of the Sovereign State." Social \& Legal Studies 17 (2): 199-215. Accessed on February 16, 2018. Available online at http://journals.sagepub.com/doi/abs/10.1177/0964663908089611

Bosworth, MARY, AND MHAIRI GuILD. 2008. "Governing through Migration Control: Security and Citizenship in Britain." British Journal of Criminology 48 (6): 703-719. Accessed on February 16, 2018. Available online at https://research.monash.edu/en/publications/governing-through-migration-control-security-and-citizenship-in-b

BroKenshiRe, JAMES. 2014. "Syria: UK Helps Vulnerable Refugees." Gov. $u k$. March 25. Accessed on February 16, 2018. Available online at https:// www.gov.uk/government/news/syria-uk-helps-vulnerable-refugees

Cabanes, Bruno. 2014. The Great War and the Origins of Humanitarianism: 1918-1924. Cambridge, UK: Cambridge University Press.

Callaghan, David. 2004. "Court Rejects Blunkett's Asylum Support Appeal." The Guardian. May 21. Accessed on February 16, 2018. Available online at https://www.theguardian.com/politics/2004/may/21/homeaffairs.uknews

CAmeron, David. 2015. "Aid for Syria and EU Reform." Department of International Development. Accessed on February 16, 2018. Available online at https://www.gov.uk/government/speeches/pm-statement-in-madrid-on-aidfor-syria-and-eu-reform

Cameron, David, And Theresa May. 2015. "Ministerial Committee for Syrian Refugees." U.K. Government, Ministry of Housing. Accessed on February 16, 2018. Available online at https://www.gov.uk/government/news/ministerial-committee-for-syrian-refugees

Cohen, Robin. 1994. Frontiers of Identity: The British and the Others. London: Longman Publishing.

Cohen, Steve. 2002. "The Local State of Immigration Controls." Critical Social Policy 22 (3): 518-543. Accessed on February 16, 2018. Available online at http://journals.sagepub.com/doi/abs/10.1177/026101830202200308

Costello, Cathryn, and Emily Hancox. 2014. "The UK, the Common European Asylum System and EU Immigration Law." The Migratiom Observatory. Accessed on February 16, 2018. Available online at http://www.migrationobservatory.ox.ac.uk/resources/primers/the-uk-the-common-european-asylum-system-and-eu-immigration-law/ 
Craig, Jon. 2015. "Refugee Crisis: PM Appears to Bow to Pressure." Sky News. Accessed on February 16, 2018. Available online at https://news.sky. com/story/refugee-crisis-pm-appears-to-bow-to-pressure-10347458

DAdDow, Oliver. 2013. "Margaret Thatcher, Tony Blair and the Eurosceptic Tradition in Britain." British Journal of Politics and International Relations 15 (2): 210-227. Accessed on February 16, 2018. Available online at http://journals.sagepub.com/doi/abs/10.1111/j.1467-856X.2012.00534.x

DARIAn-SMith, Eve. 1999. Bridging Divides: The Channel Tunnel and English Legal Identity in the New Europe. Berkeley: University of California Press.

Davey, Eleanor, John Borton, And Matthew Foley. 2013. "A History of the Humanitarian System: Western Origins and Foundations." Humanitarian Policy Group. Accessed on February 16, 2018. Available online at http://www.odi.org/publications/7535-global-history-humanitarian-action

Dembour, MARIE-BÉNÉDiCTE. 2015. When Humans Become Migrants: Study of the European Court of Human Rights with an Inter-American Counterpoint. Oxford, UK: Oxford University Press.

DüVEll, FrancK, AND BILl Jordan. 2002. "Immigration, Asylum and Welfare: The European Context." Critical Social Policy 22 (3): 498-517. Accessed on February 16, 2018. Available online at http://journals.sagepub. com/doi/abs/10.1177/026101830202200307

EGELAND, JAN. 2011. "Forward: Humanitarianism in the Crossfire." In Humanitarianism Contested: Where Angels Fear to Tread, edited by Michael N. Barnett and Thomas G. Weiss. New York, NY: Routledge. xiv-xxi.

Feldman, David. 2006. "The Boundaries of Welfare." History in Focus. Autumn. Accessed on February 16, 2018. Available online at http://www.history.ac.uk/ihr/Focus/Migration/articles/feldman.html

FLETCHER, MARIA. 2009. "Schengen, the European Court of Justice and Flexibility under the Lisbon Treaty: Balancing the United Kingdom's 'Ins' and 'Outs."' European Constitutional Law Review 5 (1): 71-98. Accessed on February 16, 2018. Available online at https://www.researchgate.net/publication/ 46214584_Schengen_the_European_Court_of_Justice_and_Flexibility_Under_ the_Lisbon_Treaty_Balancing_the_United_Kingdom's_'Ins'_and_'Outs'

Freedman, JANE. 2008. "The French 'Sans Papiers' Movement: An Unfinished Struggle." In Migration and Activism in Europe Since 1945, edited by Wendy Pojmann. New York, NY: Palgrave Macmillan. 81-96.

GEDDES, ANDREW. 2005. "Getting the Best of Both Worlds? Britain, the EU and Migration Policy." International Affairs 81 (4): 723-740. Accessed on February 16, 2018. Available online at http://onlinelibrary.wiley.com/doi/10. 1111/j.1468-2346.2005.00481.x/full 
GiBney, MATthew J. 2001. "The State of Asylum: Democratization, Judicialization and Evolution of Refugee Policy in Europe." The Refugees Convention 50 Years On: Globalisation and International Law Working Paper 50. Accessed on February 16, 2018. Available online at http://www.unhcr.org/uk/ research/working/3bf102204/state-asylum-democratization-judicialization-evolution-refugee-policy-europe.html

- 2004. The Ethics and Politics of Asylum: Liberal Democracy and the Response to Refugees. Cambridge, UK: Cambridge University Press.

2011. "Asylum Policy." The Migration Observatory. March 26. Accessed on February 16, 2018. Available online at http://www.migrationobservatory.ox.ac.uk/resources/primers/asylum-policy/

Gorman, Robert. 1994. "Poets, Playwrights, and the Politics of Exile and Asylum in Ancient Greece and Rome." International Journal of Refugee Law 6 (3): 402-424. Accessed on April 11, 2018. Available online at https://academic.oup.com/ijrl/article-abstract/6/3/402/1568168?redirectedFrom=fulltext

Goulbourne, Harry. 1998. "The Participation of New Minority Ethnic Groups in British Politics." In Race Relations in Britain: A Developing Agenda, edited by Tessa Blackstone, Bhikhu Parekh, and Peter Sanders. New York, NY: Routledge. 182-204.

Hague, William. 2000. "House of Commons Debate" (January 31), Vol. 362, column 299.

HANSEN, RANDAll. 1999. "The Kenyan Asians, British Politics and the Commonwealth Immigrants Act, 1968." The Historical Journal 42 (3): 809834. Accessed on February 16, 2018. Available online at http://web.csulb.edu/ $\sim$ ssayeghc/theory/hansen.pdf

2003. "Migration to Europe since 1945: Its History and Its Lessons." Political Quarterly 74 (1): 25-38. Accessed on February 16, 2018. Available online at http://onlinelibrary.wiley.com/doi/10.1111/j.1467-923X.2003.00579.x/ abstract

House of COMmons. 2003. "The Asylum and Immigration (Treatment of Claimants, etc.) Bill." Home Affairs Committee. Accessed on February 16, 2018. Available online at https://publications.parliament.uk/pa/cm200304/ cmselect/cmhaff/109/109.pdf

IBRAHIM, YASMIN, AND ANITA HOWARTH. 2016. "Constructing the Eastern European Other: The Horsemeat Scandal and the Migrant Other." Journal of Contemporary European Studies 74 (3): 397-413. Accessed on February 16, 2018. Available online at http://www.tandfonline.com/doi/abs/10.1080/ 14782804.2015.1135108 
2017. "Communicating the 'Migrant' Other as Risk: Space, EU and Expanding Borders." Journal of Risk Research 43 (11): 1-22. Accessed on February 16, 2018. Available online at http://www.tandfonline.com/doi/abs/ 10.1080/13669877.2017.1313765? journalCode $=$ rjrr20

- 2018. Calais and Its Border Politics; From Control to Demolition. London: Routledge.

Kaye, Ronald. 1994. "Defining the Agenda: British Refugee Policy and the Role of Parties." Journal of Refugee Studies 7 (2-3): 144-159. Accessed on February 16, 2018. Available online at https://academic.oup.com/jrs/articleabstract/7/2-3/144/1531589? redirectedFrom $=$ PDF

Kelly, Emma, and Farhat Bokhari. 2012. Safeguarding Children from Abroad: Refugee, Asylum Seeking and Trafficked Children in the UK. London: Jessica Kingsley Publishers.

Keyes, Elizabeth. 2004. "Expansion and Restriction: Competing Pressures on United Kingdom Asylum Policy." University of Baltimore School of Law. Winter. Accessed on February 16, 2018. Available online at http://scholarworks.law.ubalt.edu/cgi/viewcontent.cgi?article $=1342 \&$ context $=$ all_fac

Kleingeld, Pauline. 1998. "Kant's Cosmopolitan Law: World Citizenship for a Global Order." Kantian Review 2: 72-90. Accessed on February 16, 2018. Available online at https://openaccess.leidenuniv.nl/handle/1887/8613

Kofman, EleanORE. 2002. "Contemporary European Migrations, Civic Stratification and Citizenship." Political Geography 21 (8): 1035-1054. Accessed on February 16, 2018. Available online at https://www.researchgate. net/publication/222003952_Contemporary_European_Migrations_Civic_Stratification_and_Citizenship

Kushner, TONY. 2003. "Meaning Nothing but Good: Ethics, History and Asylum-Seeker Phobia in Britain." Patterns of Prejudice 37 (3): 257-276. Accessed on February 16, 2018. Available online at http://www.tandfonline. com/doi/abs/10.1080/00313220307593

LAUMANN, EDWARD O., AND DAVID KNOKE. 1987. The Organizational State: Social Choice in National Policy Domains. Madison: University of Wisconsin Press.

LONDON, LOUISE. 2003. Whitehall and the Jews, 1933-1948: British Policy, Jewish Refugees and the Holocaust. Cambridge, UK: Cambridge University Press.

MACDONALD, IAN. 1993. "Current Law and Practice in the UK." In The International Refugee Crisis: British and Canadian Responses, edited by Vaughan Robinson. London: Palgrave Macmillan. 158-173. 
Maughan, Bethany. 2010. "Tony Blair's Asylum Policies: The Narratives and Conceptualisations at the Heart of New Labour's Restrictionism." Oxford Department of International Development Working Paper Series 69. Accessed on February 16, 2018. Available online at https://www.rsc.ox.ac.uk/ files/files-1/wp69-tony-blairs-asylum-policies-2010.pdf

MAY, THERESA. 2015a. "Home Secretary Statement on Illegal Immigration in Calais." Home Office. July 14. Accessed on February 16, 2018. Available online at https://www.gov.uk/government/speeches/home-secretary-statementon-illegal-immigration-in-calais

- 2015b. "Home Secretary's Update on the Migration Situation in Europe and the Middle East." Home Office. September 16. Accessed on February 16, 2018. Available online at https://www.gov.uk/government/speeches/home-secretarys-update-on-the-migration-situation-in-europe-and-the-middle-east

. 2016. "PM Speech in Paris." Prime Minister's Office. July 21. Accessed on February 16, 2018. Available online at https://www.gov.uk/government/speeches/pm-statement-in-paris-21-july-2016

McAdam, Jane. 2008. Forced Migration, Human Rights and Security. Portland, OR: Bloomsbury Publishing.

McLaughlin, Carly. 2017. “"They Don't Look Like Children': Child Asylum-Seekers, the Dubs Amendment and the Politics of Childhood." Journal of Ethnic and Migration Studies. Accessed on February 16, 2018. Available online at http://www.tandfonline.com/doi/abs/10.1080/1369183X.2017.1417027

Migration News. 1995. "British Immigration Plan." Migration News. December, 2 (12). Accessed on February 16, 2018. Available online at https:// migration. ucdavis.edu/mn/more.php?id $=820$

Miles, Robert. 1989. Racism. London: Routledge.

Miles, Robert, and Paula Cleary. 1993. "Migration to Britain: Racism, State Regulation and Employment." In The International Refugee Crisis, edited by Vaughan Robinson. London: Palgrave Macmillan. 57-75.

Minderhoud. PAul. 1999. "Asylum Seekers and Access to Social Security: Recent Developments in The Netherlands, United Kingdom, Germany and Belgium." In Refugees, Citizenship and Social Policy in Europe, edited by Alice Bloch and Carl Levy. Basingstoke, UK: Palgrave Macmillan. 132-148.

MORRIS, LYDIA. 1998. "Governing at a Distance: The Elaboration of Controls in British Immigration." International Migration Review 32 (4): 949-973. Accessed on February 16, 2018. Available online at https://www.ncbi.nlm. nih.gov/pubmed/12294303 
2009. "An Emergent Cosmopolitan Paradigm? Asylum, Welfare and Human Rights." The British Journal of Sociology 60 (2): 215-235. Accessed on February 16, 2018. Available online at https://www.ncbi.nlm.nih.gov/ pubmed/19489817

Mulvey, Gareth. 2010. "When Policy Creates Politics: The Problematizing of Immigration and the Consequences for Refugee Integration in the UK." Journal of Refugee Studies 23 (4): 437-462. Accessed on February 16, 2018. Available online at https://academic.oup.com/jrs/article/23/4/437/1530930

O’Neill, Graham. 2017. "The Government Is Trying to Starve Refugees Out of the UK. It Doesn't Work." The Guardian. Accessed on February 16, 2018. Available online at https://www.theguardian.com/voluntary-sector-network/2017/may/31/government-starve-refugees-out-of-uk-poverty

Panayi, Panikos, AND PiPPA Virdee. 2011. Refugees and the End of Empire: Imperial Collapse and Forced Migration in the Twentieth Century. Basingstoke, UK: Palgrave Macmillan.

Partos, Rebecca, And Tim Bale. 2015. "Immigration and Asylum Policy under Cameron's Conservatives." British Politics 10 (2): 169-184. Accessed on February 16, 2018. Available online at https://www.researchgate.net/publication/ 275248072_Immigration_and_asylum_policy_under_Cameron's_Conservatives

Rabben, Linda. 2011. Give Refuge to the Stranger: The Past, Present and Future of Sanctuary. Walnut Creek, CA: Left Coast Press, Inc.

Refugee ACtion. 2017. "Slipping through the Cracks: How Britain's Asylum Support System Fails the Most Vulnerable." Refugee Action. July. Accessed on February 16, 2018. Available online at http://www.refugeeaction.org.uk/wp-content/uploads/2017/06/Slipping-through-the-cracks-final4A4-1.pdf

Refugee CouncIL. 2015. "The 'Dublin' Regulation and Family Unit.” Refugee Council. Accessed on February 16, 2018. Available online at https:// www.refugeecouncil.org.uk/assets/0003/6143/Nov15_Dublin_III.pdf

. n.d. "Safe Country of Origin: United Kingdom." Accessed on February 16, 2018. Available online at http://www.asylumineurope.org/reports/country/united-kingdom/asylum-procedure/safe-country-concepts/safe-country-origin

RogERS, JUSTIN. 2017. "There Is Space for Lone Refugee Children in Britain, but the Government Isn't Trying to Find It." The Conversation. February 15. Accessed on February 16, 2018. Available online at https://theconversation.com/there-isspace-for-lone-refugee-children-in-britain-but-the-government-isnt-trying-to-findit-72818

SAles, Rosemary. 2002. "The Deserving and the Undeserving? Refugees, Asylum Seekers and Welfare in Britain." Critical Social Policy 22 (3): 456- 
478. Accessed on February 16, 2018. Available online at http://journals.sagepub.com/doi/abs/10.1177/026101830202200305

- 2005. "Secure Borders, Safe Haven: A Contradiction in Terms." Ethnic and Racial Studies 28 (3): 445-462. Accessed on February 16, 2018. Available online at http://www.tandfonline.com/doi/abs/10.1080/0141987042000337830

SAlLinen, HARRI. 2013. Intergovernmental Advocates of Refugees: The Refugee Policy of the League of Nations and the International Labour Organization in the 1920s and 1930s. Doctoral dissertation, Department of Economic and Political Studies, Helsinki University. Accessed on February 16, 2018. Available online at https://helda.helsinki.fi/handle/10138/41070

Schuster, LizA, And John Solomos. 1999. "The Politics of Refugee and Asylum Policies in Britain: Historical Patterns and Contemporary Realities." In Refugees, Citizenship and Social Policy in Europe, edited by Alice Bloch and Carl Levy. Basingstoke, UK: Palgrave MacMillan. 51-75.

—. 2001. "Asylum, Refuge and Public Policy: Current Trends and Future Dilemmas." Sociological Research Online 6 (1). Accessed on February 16, 2018. Available online at http://www.socresonline.org.uk/6/1/schuster.html

Sellar, Christian, Caedmon Staddon, and Craig Young. 2009. "Twenty Years after the Wall: Geographical Imaginaries of 'Europe' during European Union Enlargement." Journal of Cultural Geography 26 (3): 253258. Accessed on February 16, 2018. Available online at http://www.tandfonline.com/doi/full/10.1080/08873630903322189

SHAw, CAROLINE. 2015. Britannia's Embrace: Modern Humanitarianism and the Imperial Origins of Refugee Relief. Oxford, UK: Oxford University Press.

SHEIKH, USMAN. 2016. "Theresa May's Dangerous Record on Immigration." OpenDemocrac. July 22. Accessed on March 28, 2018. Available online at https:// www.opendemocracy.net/uk/usman-sheikh/theresa-mays-dangerous-record-onimmigration

Shoemaker, Karl. 2011. Sanctuary and Crime in the Middle Ages, 4001500. New York, NY: Fordham University Press.

Silverman, Stephanie J., AND Ruchi Hajela. 2015. "Briefing: Immigration Detention in the UK." The Migration Observatory. February 6. Accessed on February 16, 2018. Available online at http://www.migrationobservatory.ox. ac.uk/wp-content/uploads/2016/04/Briefing-Immigration_Detention.pdf

Simms, BRENDAN, AND DAVID J. B. TRIM. 2011. Humanitarian Intervention: A History. Cambridge, UK: Cambridge University Press.

SimpSON, BRIAN A. W. 2004. Human Rights and the End of Empire: Britain and the Genesis of the European Convention. Oxford, UK: Oxford University Press. 
Singh, ANNE. 2010. "A Cashless Society: The Other Side of the Coin." Institute of Race Relations. Accessed on February 16, 2018. Available online at http://www.irr.org.uk/news/a-cashless-society-the-other-side-of-the-coin/

SKINNER, RoB, AND AlAn LeSTER. 2012. "Humanitarianism and Empire: New Research Agendas." The Journal of Imperial and Commonwealth History 40 (5): 727-747. Accessed on February 16, 2018. Available online at http:// www.tandfonline.com/doi/abs/10.1080/03086534.2012.730828

Solomos, John. 1993. Race and Racism in Britain. 2d edition. London: MacMillan.

Spencer, IAN R. G. 1997. British Immigration Policy since 1939: The Making of Multi-Racial Britain. London: Routledge.

Stoecker, Ralf. 2011. "Three Crucial Turns on the Road to an Adequate Understanding of Human Dignity." In Humiliation, Degradation, Dehumanization: Human Dignity Violated, edited by Paulus Kaufmann, Hannes Kuch, Christian Neuhauser, and Elaine Webster. Dordrecht, the Netherlands: Springer. 7-17.

Summers, Deborah. 2007. "Government Loses Sham Marriages Appeal." The Guardian. May 23. Accessed on February 16, 2018. Available online at https://www.theguardian.com/politics/2007/may/23/immigrationpolicy.immigration

THE GUARDiAn. 2009a. "Asylum and Immigration (Treatment of Claimants) Act 2004." The Guardian. January 19. Accessed on February 16, 2018. Available online at https://www.theguardian.com/commentisfree/libertycentral/ 2009/jan/15/civil-liberties-immigration

. 2009b. "Nationality, Immigration and Asylum Act 2002." The Guardian. January 15. Accessed on February 16, 2018. Available online at https://www.theguardian.com/commentisfree/libertycentral/2009/jan/15/nationality-immigration-asylum-act

Travis, Alan. 2013. "Immigration Bill: Theresa May Defends Plans to Create "Hostile Environment."' The Guardian. October 10. Accessed on February 16, 2018. Available online at https://www.theguardian.com/politics/2013/oct/ 10/immigration-bill-theresa-may-hostile-environment

- 2017. "Charities Criticise New Government Rules on 'Dubs' Child Refugees." The Guardian. March 14. Accessed on February 16, 2018. Available online at https://www.theguardian.com/world/2017/mar/14/charities-criticise-government-rules-on-dubs-child-refugees

United NATIONS. 1951. "Convention Relating to the Status of Refugees." Accessed on February 16, 2018. Available online at http://www.unhcr.org/uk/ 3b66c2aa 10 
1967. "Protocol Relating to the Status of Refugees." Accessed on February 16, 2018. Available online at http://www.unhcr.org/uk/3b66c2aa10

UNited NATIONS High COMMissioner fOR REFUGEES (UNHCR). 2014. Asylum in the UK. Geneva, Switzerland: United Nations.

United Nations.

2017. Europe Situation. Geneva, Switzerland: United Nations.

WAdsworth, Jonathan, Swati Dhingra, Gianmarco OtTAViano, AND JOHN VAN REENEN. 2016. "Brexit and the Impact of Immigration on the UK." Centre for Economic Performance, LSE. Accessed on February 16, 2018. Available online at http://cep.lse.ac.uk/pubs/download/brexit05.pdf

WALl, StePhen. 2012. "Britain and Europe." The Political Quarterly 83 (2): 1191-1203. Accessed on February 16, 2018. Available online at http://onlinelibrary.wiley.com/doi/10.1111/j.1467-923X.2012.02312.x/abstract

WATt, Nicholas, AND PATRICK Wintour. 2015. "How Immigration Came to Haunt Labour: The Inside Story." The Guardian. March 24. Accessed on February 16, 2018. Available online at https://www.theguardian. com/news/2015/mar/24/how-immigration-came-to-haunt-labour-inside-story

WebBer, Frances. 2008. Border Wars and Asylum Crimes. London, UK: Statewatch.

Wintour, PATRICK. 2015. "Britain Should Not Take More Middle East Refugees, Says David Cameron”. The Guardian. September 3. Accessed on February 16, 2018. Available online at https://www.theguardian.com/world/2015/sep/02/ david-cameron-migration-crisis-will-not-be-solved-by-uk-taking-in-more-refugees

. 2017. "1M African Migrants May be En Route to Europe, Says Former UK Envoy." The Guardian. April 2. Accessed on February 16, 2018. Available online at https://www.theguardian.com/uk-news/2017/apr/02/1mafrican-migrants-may-be-en-route-to-europe-says-former-uk-envoy

Yuval-Davis, Nira, Georgie Wemyss, And Kathryn CASsidy. 2017. "Everyday Bordering, Belonging and the Reorientation of British Immigration Legislation." Sociology 52 (2): 228-244. Accessed on February 16, 2018. Available online at http://journals.sagepub.com/doi/10.1177/0038038517702599

Zetter, Roger, David Griffiths, And Nando Sigona. 2005. "Social Capital or Social Exclusion? The Impact of Asylum-Seeker Dispersal on UK Refugee Community Organizations." Community Development Journal 40 (2): 169-181. Accessed on February 16, 2018. Available online at https://www.rsc. ox.ac.uk/publications/social-capital-or-social-exclusion-the-impact-of-asylumseeker-dispersal-on-uk-refugee-community-organizations 